\title{
CITRA GERAKAN POLITIK ISLAM DALAM LINTASAN SEJARAH PERPOLITIKAN BANGSA INDONESIA \\ (Studi Era Pra Kemerdekan sampai dengan Era Orde Baru)
}

\author{
Kamsi \\ Dekan Fakultas Ilmu Sosial Humaniora UIN \\ Sunan Kalijaga Yogyakarta \\ email: kamsi@uin-suka.ac.id
}

\section{ABSTRACT}

In the pre-independence era and towards independence era of Indonesia, muslims become a political force that taken into account, it means muslims have an authority to make a decision that influence the future of Indonesia. The position of muslim was continoued until the birth of the Old Order. In the era of the Old Order or Democracy Guided, about relationship between muslims and the state at the time, the Muslims devided into two groups of political patterns, first ijtihad, it is better for muslims to get into the system for the sake of Islam, while second ijtihad recommended that muslims must fight the system for the sake of Islam. In the era of the New Order, the relationship between muslim and state was very unique, which was cordial in beginning, conflicting for long time, and finally going into intimate at the end of the era.

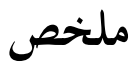

في عصر ما قبل الإستقلال ونحو عصرإستقلال اندونيسيا، كان المسلمون أصبحوا قوة سياسية معينة، بمعنى أن المسلمين لديهم السلطة لاتخاذ القرار الذي يؤثر على مستقبل إندونيسيا. واستمر موقف المسلمين حتى ولادة النظام القديم.ي عهد النظام القديم أو الديمقراطية الموجهة، حول العلاقة بين المسلمين والدولة في ذلك الوقت، يقسم المسلمون الى بحموعتين من الأنماط السياسية. الاجتهاد الأول، فمن الأفضل للمسلمين للوصول الى النظام من أجل الإسلام. والاجتهاد الثاني،يجب للمسلمون 


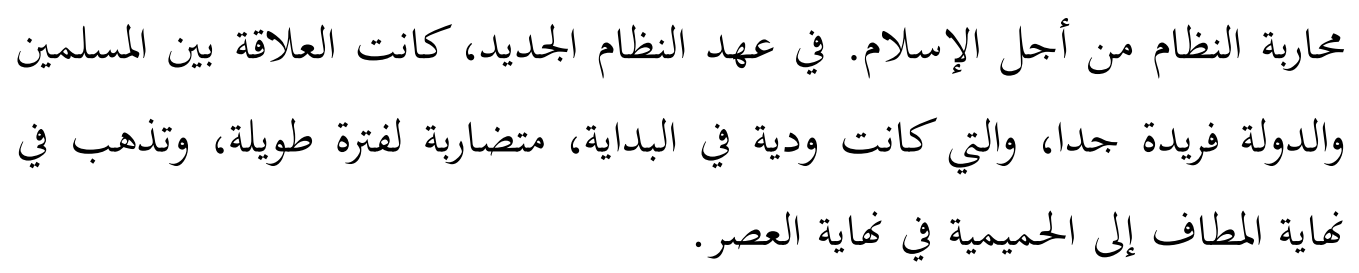

Keywords: politik muslim, Orde lama, Orde Baru, ijtihad politik.

\section{A. Pendahuluan}

Dalam catatan sejarah masa lalu, sekarang dan masa-masa yang akan datang, peranan gerakan politik Islam hampir selalu menempati posisi yang menentukan dalam proses sosial politik dalam negara dan masyarakat. Untuk kasus Indonesia sosok ini pernah begitu tegar dalam masa perjuangan kemerdekaan melawan penjajah.

Gambaran yang sama juga tercermin dalam gerak, posisi dan fungsi politik Islam dalam era Orde Lama. Suasana saat itu boleh jadi merupakan arena politisasi dalam semua sektor aktivitas. Bagi para aktivis partai politik atau buat nereka yang duduk di struktur kekuasaan saat itu, peranan politik Islam selalu dilihat sebagai asset perjuangan dan kepentingan politik, karena itu tidak heran jika masa itu diwarnai dengan munculnya kegiatan berbagai organisasi politik Islam.

Bagaimana peran dan posisi politik Islam di era Orde Baru, pada masa ini sebagai reaksi terhadap apa yang terjadi pada masa Orde Lama, ada berbagai kebijakan pemerintah yang secara relatif dapat diartikan sebagai upaya depolitisasi masyarakat, dan priorotas diberikan kepada pembangunan ekonomi. Ini ditujukan dengan empat ujung tombak kebijakan pemerintah yang dikeluarkan secara bertahap, yakni kebijakan floating-mass, penyederhanaan partai politik. Undang-Undang Partai Politik dan Keormasan serta Pelaksanaan Asas Tunggal Pancasila terhadap partai politik dan organisasi masyarakat yang ada. Pertanyaannya adalah bagaimana peran gerakan politik Islam.

Untuk mengetahui ini akan dipaparkan gerakan politik Islam pada pra kemerdekaan dan awal kemerdekaan Republik Indonesia sampai dengan masa Orde Baru. Bagaimana keberadaan Islam dan politik di era tersebut. 


\section{B. Gerakan Politik Islam dalam Lintasan Sejarah}

\section{Gerakan Politik Islam pada Era Pra dan Awal Kemerdekaan}

Persoalan yang menarik bahkan unik pada masa ini adalah wacana dan perdebatan tentang konsep kebangsaan yang juga membawa gagasan Islam sebagai dasar negara dan gagasan lain yang menghendaki berlakunya negara dan hukum lain yang juga berakar dalam kehidupan rakyat Indonesia. ${ }^{1}$ Karena itu berdasarkan catatan sejarah bangkitnya nasionalisme Indonesia pada masa ini ditandai dengan munculnya pergerakan di negeri ini berjuang melawan kolonial Belanda untuk segera bebas dari cengkeraman penjajah ini. Dalam perjuangan ini Islam mempunyai peran penting dalam menentukan eksistensi negeri ini ke depan, dan secara historis dapat diikuti perdebatan tentang apakah negara merdeka kelak berideologi Islam atau non Islam.

Pertama, pada tahun 1916, muncul heboh Jawi Hisworo, yaitu pertarungan politik antara perjuangan ideologi non Islam melawan Islam. Ketika itu sebuah koran berbahasa Jawa Jawi Hisworo memuat tulisan yang menghina Nabi Muhammad dengan mengatakannya sebagai pemabuk dan pemadat yang tentu saja kemudian membangkitkan umat Islam untuk membela haknya disertai muatan gagasan bahwa masyarakat perlu diatur secara Islam, seperti yang disyariatkan melalui Nabi Muhammad Saw. Gerakan ini secara gencar disuarakan antara lain oleh Sarekat Islam. Menghadapi reaksi umat Islam seperti ini pada tahun 1918 pendukung Jawi Hisworo membentuk Panitia Kebangsaan Jawa. Panitia ini mengecam gerakan kelompok Sarekat Islam dalam kehidupan politik untuk memperjuangkan kemerdekaan Indonesia. Kelompok ini menandaskan bahwa politik dan agama harus dipisah, sedang kelompok Sarekat Islam justru ingin mengaitkan politik dengan agama.

Kedua, Soekarno dan Natsir pada era ini telah melakukan polemik ${ }^{2}$ tentang Islam dan Negara. Polemik ini diawali dari tulisan Soekarno dalam Panji Islam

1 Moh. Mahfud MD, "Perjuangan dan Politik Hukum Islam di Indonesia” dalam Syamsul Anwar, Antologi Pemikiran Hukum Islam di Indonesia antara Idealitas dan Realitas, (Yogyakarta: Fakultas Syari’ah UIN Sunan Kalijaga, 2008), hal. 60.

2 Polemik antara dua tokoh ini juga terjadi pada masa pascakemerdekan hanya saja objeknya kebijakan merebut Irian Barat. Mereka berbeda pemikiran strategi politik walaupun mempunyai dampak yang sama, yaitu ujungnya pada persoalan ideologi antara Nasionalis dengan Islam. Lihat A. Syafii Maarfif, Islam dan Politik di Indonesia pada Masa Demokrasi 
dengan judul Memudakan Pengertian Islam. Tulisan ini semula dimaksudkan untuk menanggapi tulisan K.H. Mas Mansur yang berjudul Memperhatikan Gerakan Pemuda di dalam Majalah Adil dan Panji Islam. Tulisan Soekarno berisi kritik tajam terhadap kekolotan Islam yang dikatakannya perlu dikoreksi pengertian-pengertiannya. Soekarno mengajakagar paham dan pemikiran Islam selalu diperbaharui dan tidak dipertahankan secara kolot sebab hukum-hukum Islam itu dapat selalu menyesuaikan dengan kultur dan perkembangan keadaan dan dapat cocok dengan kemajuan. Selain itu dalam tulisan Soekarno ini juga menyinggung hubungan negara dengan agama, yaitu demi kebaikan bahwa agama dan negara keduanya harus dipisahkan sebagai mana dikemukakan oleh Kemal at-Taturk pada tahun 1928. Tulisan Soekarno selanjutnya ditanggapi oleh Natsir dengan nama samaran Muchlis dalam Majalah al-Manar dan Panji Islam dengan judul Perskot dengan melontarkan keheranannya terhadap Soekarno yang mengagungkan Kemal at-Taturk yang memisahkan negara dengan agama, dan mengapa pula Soekarno untuk menolak persatuan negara dan agama dengan alasan tidak ada ijmak. Maka dalam tulisannya Natsir membalik logika Soekarno tentang ijmak dengan menanyakan, kalau tidak ada ijmak tentang persatuan negara dan agama, maka adakah ijmak tentang keharusan memisahkan antara agama dan negara. Oleh karena itu pandangan Soekarno ini ditolak tidak dapat diterima karena tidak ada ijmak. ${ }^{3}$

Ketiga. pengalaman berikutnya adalah perdebatan secara formal ada di Badan Penyelidik Usaha-Usaha Persiapan Kemerdekaan (BPUPKI) yang dibentuk pada bulan April 1945 maupun dalam Panitia Persiapan Kemerdekaan Indonesia (PPKI), suatu badan yang dibentuk untuk menyatakan kemerdekaan, melakukan pengalihan kekuasaan, mensahkan konstitusi, dan membentuk pemerintahan bagi Indonesia jika akan merdeka. ${ }^{4}$

Di sinilah puncak pertentangan tersebut tampak semakin jelas ketika proses pembentukan dasar negara Republik Indonesia. Pertentanganpertentangan seperti ini, selain memang telah ada sebelum Jepang datang, sebenarnya hasil maksimal dari proses devide et empera yang dilakukan

Terpimpin (1959-1965) (Yogyakarta: IAIN Sunan Kalijaga Press, 1988) hal. 73-77

3 Moh. Mahfud MD, "Perjuangan dan Politik Hukum Islam di Indonesia....", hal. 63-64.

$4 \quad$ Ibid. hal. 66. 
Jepang untuk memperkuat kedudukannya. ${ }^{5}$ Dengan kata lain ketegangan antara golongan Islam dan nasionalis menjadi jelas ketika Jepang membentuk BPUPKI dan sidang-sidangnya ketika membahas dasar Negara, dengan bentuk kolaborasi dengan beberapa kelompok bangsa Indonesia. Ketika itu bangsa Indonesia setidak-tidaknya dapat dikelompokkan menjadi tiga macam kelompok yaitu elite nasionalis, elite priyayi, dan elite Islam. Dalam melangsungkan kolaborasinya, ketiga kelompok ini diakomodasi secara bergantian, ${ }^{6}$ sehingga sejak itu hubungan politik Islam dan negara terjadi saling curiga mencurigai atau hubungan antagonistik. ${ }^{7}$

Pada sidang pleno ke-2 tanggal 10-16 Juli 1945 dicapai kesepakatan tentang dasar negara dan UUD negara yakni Piagam Jakarta dan UUD 1945. Piagam Jakarta yang dituangkan dalam rancangan Mukadimah mengakomodasi Islam sebagai dasar negara khusus bagi umat Islam, yang dimasukkan di dalam sila pertama dengan kalimat "Ketuhanan dengan kewajiban menjalankan syari at Islam bagi pemeluknya."

Terlepas dari isinya yang memang tak diperdebatkan, penyusun Mukadimah dengan Piagam Jakarta dijelaskan oleh kedua sumber buku secara berbeda. Menurut keterangan Yamin sebagaimana dijelaskan oleh Mahfud, Piagam Jakarta itu disusun oleh Panitia Sembilan yang ditunjuk oleh BPUPKI pada sidang tanggal 1 Juni $1945,{ }^{8}$ tetapi menurut AB Kusuma dikemukakan bahwa sebenarnya Panitia Sembilan itu tidak pernah dibentuk oleh BPUPKI, melainkan dibentuk secara spontan dan tidak prosedural oleh Soekarno karena perkembangan situasi Perang Dunia II yang sedang memanas pada saat itu. Pendapat AB Kusuma ini didasarkan pada isi pidato Bung Karno sendiri yang meminta maaf kepada sidang BPUPKI karena telah mengumpulkan 9 orang secara tidak prosedural untuk menyusun rancangan Pembukaan UUD yang oleh Ir. Soekarno diberi judul “Mukadimah”, oleh Yamin diberi nama “Piagam

5 Harry J. Benda, Bulan Sabit dan Matahari Terbit Islam Indonesia pada Masa Pedudukan Jepang, alih bahasa: Daniel Dhakidae, (Jakarta: Pustaka Jaya, 1980), hal. 185.

$6 \quad$ Ibid., hal. 209 dan 243.

7 Hubungan Antagonistik, adalah pola hubungan yang mencerminkan hubungan yang hegemonik anatara Islam dengan pemerintah. Dapat dilihat dalam M. Syafi'i Anwar, Pemikiran dan Aksi Islam Indonesia: Sebuah Kajian Politik tentang Cendekiawan Muslim Orde Baru, (Jakarta: Paramadina, 1995), hal. 9.

8 Moh. Mahfud MD, "Perjuangan dan Politik Hukum Islam di Indonesia....", hal. 66. 
Jakarta" dan oleh Dr. Sukiman disebut dengan Gentlemen`s Agreement karena belum menjadi keputusan BPUPKI. ${ }^{9}$.

Perebutan pengaruh politik antar dua kubu, yaitu Islam dan nasionalis pada era ini tampak ketat yang demikian terlihat dalam perdebatan pada sidang-sidang di BPUPKI/PPKI. Kelompok Islam menyatakan bahwa Indonesia kelak harus menjadi negara Islam atau Islam menjadi ideologi negara. Kelompok nasionalis mengusulkan dibentuknya sebuah negara kesatuan nasional. Dalam perkembangan berikutnya kelompok Islam pecah menjadi dua, yaitu kubu yang tetap ingin ideal dengan cita-cita negara Islam dan kubu yang bersikap akomodatif. Sementara kelompok Nasionalis pecah menjadi dua juga, yakni nasionalis sekuler dan nasionalis agamis. Kelompok Islam akomodasionis inilah yang sekarang bersama dengan nasionalis agamis berusaha untuk memperjuangkan Islam bukan dari labelnya tetapi substansialnya. ${ }^{10}$

Perdebatan ini merupakan polemik yang tidak pernah berkesudahan sejak BPUPKI/PPKI pada tahun 1945, masa Orde Lama, masa Orde Baru dan bahkan sampai pada Orde Reformasi tema ini muncul kembali melalui perdebatan pasal 29 UUD 1945 yang bergulir pada Sidang Tahunan MPR. Dua fraksi partai Islam yaitu Fraksi Partai Persatuan Pembangunan (F-PPP) dan Fraksi Bulan Bintang (F-PBB) dalam pemandangan umum mereka bersikeras untuk memasukkan kembali Piagam Jakarta dalam batang tubuh UUD 1945, khususnya pasal 29. Mereka menegaskan dengan ditambahkannya tujuh kata seperti dalam Piagam Jakarta itu tidak berarti akan terbentuknya negara Islam. ${ }^{11}$

Arah sejarah berbelok lagi, pada sidang PPKI tanggal 18 Agustus 1945 tujuh kata yang ada pada Piagam Jakarta yang selanjutnya menjadi dasar berlakunya hukum Islam di Indonesia dicoret. Pencoretan tujuh kata itu diakui oleh Hatta sebagai prakarsanya yang telah disetujui oleh wakil Islam di PPKI, yaitu Ki Bagus Hadikusumo, KH. Wahid Hasyim, Tengku M. Hasan, dan Kasman Singodimejo. Latar belakang pencoretan itu sendiri, kata Hatta karena

9 MR. AB. Kusuma, Lahirnya Undang-Undang Dasar 1945, (Jakarta: Badan Penerbit Fakultas Hukum Universitas Indonesia, 2004), hal. 21.

10 Ratno Lukito, Hukum Islam dan Realitas Sosial, (Yogyakarta: Fakultas Syari ah UIN Sunan Kalijaga, 2008), hal. 61.

11 Arskal Salim and Azyumardi Azra, 'Introduction The State and Shari 'a in the Perspective of Indonesian Legal Politics' dalam Arskal Salim and Azyumardi Azra (ed.), Shari 'a and Politics in Modern Indonesia, (Singapore: Institute of Southeast Asian Studies, 2003), hal. 1. 
pada sore hari tanggal 17 Agustus 1945 dirinya didatangi oleh seseorang dari bagian timur Indonesia yang diantar oleh Maeda (penguasa militer di Jakarta) dan meminta agar tujuh kata dalam Piagam Jakarta itu dicoret, ${ }^{12}$ karena bersifat diskriminatif. Menurut orang itu, jika tujuh kata tidak dicoret pihaknya lebih baik tidak ikut merdeka bersama Indonesia. Itulah sebabnya sebelum sidang PPKI tanggal 18 Agustus 1945 itu dimulai, Hatta meminta empat tokoh yang disebutkan di atas.

Beberapa masalah yang kemudian muncul. Pertama, siapa dan atas mandat dari mana orang bagian timur Indonesia itu sehingga mendorong Hatta melakukan pencoretan? Kedua, Maeda (sesuai dengan interview Seichi Okawa dari majalah Tempo bulan Agustus 1995) yang oleh Hatta dikatakan sebagai pengantar orang timur Indonesia itu ternyata menyatakan tak tahu-menahu dan tak pernah mengantarkan orang bertemu Hatta untuk urusan seperti itu meskipun diakui sore hari tanggal 17 Agustus 1945 dirinya memang bertemu Hatta. Ketiga, Wahid Hasyim yang kata Hatta dimintai pendapatnya sebelum sidang dimulai, kabarnya pada hari itu tidak hadir pada sidang BPUPKI karena ada acara NU di Jawa Timur. Keempat, Kasman Singodimejo dan Tengku M. Hasan adalah anggota PPKI yang baru yang dulunya tidak menjadi anggota BPUPKI sehingga ia tak pernah ikut menghayati perbedaan-perbedaan dan kompromi yang kemudian dicapai. ${ }^{13}$ Kelima, kemungkinan secara pribadi Hatta adalah dilatarbelakangi oleh pendidikannya, yaitu sebagai sarjana produk dari Belanda sehingga ketika itu kurang menghayati kondisi riil bangsa (umat Islam) saat itu, dan kurang perhatiannya terhadap rumusan Piagam Jakarta yang diketuai Soekarno yang merupakan sarjana produk dalam negeri sehingga lebih menghayati kondisi rii saat itu. Dari sini muncullah perbedaan yang mendasar antara dua tokoh proklamator ini, yakni Hatta termasuk 'golongan kebangsaan` yang dikenal menjunjung tinggi nilai demokrasi Barat yang menganut pemisahan secara mutlak antara agama dan negara, dan ini berbeda dengan Soekarno yang tidak sepenuhnya menganut paham pemisahan agama dan negara. ${ }^{14}$

12 Lihat dalam A. Syafi i Maarif, Islam dan Politik di Indonesia pada Masa Demokrasi Terpimpin (1959-1965), (Yogyakarta: IAIN Sunan Kalijaga Press, 1988), hal. 29.

${ }^{13}$ Moh. Mahfud MD, “Perjuangan dan Politik Hukum Islam di Indonesia....", hal. 69.

${ }^{14}$ Haedar Nashir, Gerakan Islam Syari at Reproduksi Salafiyah Ideologis di Indonesia, (Jakarta: Pusat Studi Agama dan Peradaban (PSAP) Muhammadiyyah, 2007), hal. 234-235. 
Berdasarkan disertasi yang ditulis oleh Polen tahun 1971 sebagaimana dikutip Mahfud MD, "pencoretan tujuh kata tersebut adalah konspirasi antara Soekarno, Hatta." Sementara itu orang timur yang dimaksud tidak ada sama sekali. Hal itu dilakukan karena jauh sebelum Indonesia merdeka, Jepang telah berpesan bahwa kalian boleh merdeka akan tetapi jangan Negara Islam. ${ }^{15}$

Setelah tanggal 18 Agustus 1945 perjuangan umat Islam untuk kembali ke Piagam Jakarta atau perjuangan untuk menjadikan Islam sebagai dasar negara berlanjut lagi. Selama beberapa tahun setelah proklamasi kemerdekaan tidak ada persoalan yang serius terkait dengan hubungan arus politik antara golongan Islam dengan nasionalis terlupakan, baru muncul lagi yaitu di ajang pergumulan Majlis Konstituante (1956-1959) hasil Pemilihan Umum 1955 yang ditulangpunggungi oleh Masyumi dan NU memperjuangkan dasar negara Islam di sidang-sidang Konstituante namun tidak berhasil sampai akhirnya Konstituante dibubarkan dengan Dekrit Presiden 5 Juli 1959. Komitmen dari kedua partai Islam untuk memperjuangkan Negara Islam adalah tidak lepas dari kekalahan golongan Islam dengan dihapuskannya Piagam Jakarta. Konfigurasi politik pada saat itu terbagi menjadi tiga ideologi besar, yaitu kekuatan politik dengan ideologi Islam yang diwakili oleh Masyumi, PSII, PERTI dan NU; ideologi Nasionalis diwakili oleh PNI, dan ideologi Marxis-Sosialis diwakili oleh Partai Sosialis, PKI, Partai Buruh Indonesia dan Persindo, serta partaipartai lainnya.

Dari fakta sejarah di atas tampak pertama, adanya dialektika antara struktur politik dengan aturan main yang dibuat sangat ketat. Struktur politik yang sangat kondusif kepada demokrasi telah mengakibatkan munculnya aturanaturan hukum yang suportif terhadap pelaksanaan hak-hak warga negara. Oleh karena itu pada era rezim Demokrasi Parlementer ini di Indonesia terdapat peluang yang sangat besar bagi proses demokratisasi. Namun sebagaimana kita ketahui momentum seperti ini tidak dapat dimanfaatkan oleh pemimpin kita sehingga sirnalah percobaan Demokrasi Parlementer setelah Presiden mengeluarkan Dekrit Presiden 5 Juli 1959. ${ }^{16}$

${ }^{15}$ Moh. Mahfud MD, "Politik Hukum Islam di Indonesia” dalam Seninar Jurusan Jinayah Siyasah FakultasSyariah UIN Sunan Kalijaga pada 25 November 2006, bertempat di Aula Balai Diklat Depsos, Jogjakarta.

16 Muhammad AS. Hikam, "Politik Hukum di Indonesia dalam Konteks Reformasi dan Demokrasi", dalam Khamami Zada - Idy Muzayyad (ed.), Wacana Politik Hukum dan 
Kedua, adanya ketegangan tensi politik di Majelis Konstituante yang tidak pernah mereda antara kelompok nasionalis dan kelompok Islam dalam perebutan ideologi negara, artinya erakan politik Islam belum menunjukkan sebuah hubungan yang harmonis atau berada pada bentuk hubungan antagonistik. Menurut analisis Bachtiar Effendi, sebagaimana dikutip oleh Akhmad Satori, kondisi dinamika politik pada era ini adalah menunjukkan pemikiran dan praktek politik Islam masa lalu mengalami kesenjangan yang tidak terjembatani dengan ide-ide politik kalangan nasionalis. Padahal kalangan nasionalis ini sebagian terdiri dari orang-orang muslim yang taat, mereka tidak mendukung gagasan politik yang ingin menghubungkan Islam dengan negara secara formalistik dan legalistik. ${ }^{17}$ Kesenjangan gerakan politik Islam dan negara ini terjembatani terjadi pada dasa warsa ketiga dari era Orde Baru sebagaimana akan penulis jelaskan pada pembahasan hubungan negara dan Islam di era Orde Baru.

Di antara perdebatan yang menarik atau menjadi masalah yang hangat dibicarakan dalam sidang-sidang Konstituante tahun 1956-1959 adalah masalah Undang-Undang Dasar karena memang tugas badan tersebut ialah membuat Undang-Undang Dasar. Tugas Konstituante menyusun Undang-Undang Dasar adalah amanat dari Undang-Undang Dasar Sementara 1950. Setelah pada permulaan tahun 1959 Konstituante menyelesaikan 90\% dari pekerjaannya, kemudian pekerjaan ini dikesampingkan lebih dulu karena ada usul dari pemerintah agar UUD 1945 berlaku kembali, dan sepertinya Konstituante bersimpati terhadap usul ini namun jumlah suara di Konstituante yang setuju terhadap usul ini tidak mencapai 2/3 dari seluruh jumlah anggota Konstituante, artinya berdasarkan itu usul pemerintah ditolak. Wilopo dari PNI sebagai ketua Kontituante dan Prawoto Mangkusasmito dari Masyumi sebagai wakil ketuanya selanjutnya menyarankan melanjutkan menyelesaikan pekerjaan yang tinggal 10\% dan ditarget paling lambat bulan Maret 1960 sudah selesai. Tidak banyak orang tahu bahwa kedua tokoh Konstituante tersebut telah juga sepakat untuk menerima kelima sila yang disebut Pancasila itu sebagai dasar negara dalam

Demokrasi Indonesia, (Yogyakarta: Senat Mahasiswa Fakultas Syari ah IAIN Sunan Kalijaga1999), hal. 7.

17 Akhmad Satori, “Wacana Negara Islam dalam Parlemen Konstituante: Hubungan Antagonistik Islam dan Negara di Indonesia", Sabtu, 07 Juni 2008, dalam http:/ / sitisalbiahnur.blogspot.com/. Diakses 17 Mei 2011. 
rangka pembuatan undang-undang dasar baru tadi, hal ini disampaikan kepada Mohammad Hatta sebelum ada usul pemerintah untuk kembali kepada UUD 1945. Tetapi pihak tentara dan sebagian anggota Konstituante dari PNI yang dipimpin oleh Suwirjo tidak sabar dan mendesak kepada Presiden Soekarno (yang ketika itu ada di Tokyo) untuk mendekritkan UUD 1945, dan inilah yang terjadi pada bulan Juli 1959, segera setelah Presiden Soekarno kembali ke tanah air. ${ }^{18}$

\section{Gerakan Politik Islam pada Era Orde Lama}

Adu kekuatan politik ini bukan hanya di Konstituante bahkan juga di masyarakat begitu gencar sehingga tidak pernah mencapai kesepakatan tentang dasar negara di antara elite, yaitu nasionalis sekuler dan nasionalis Islam dan kedua kelompok ini tidak pernah memperoleh dukungan minimal untuk sebuah keputusan. Dalam polarisasi politik yang seperti inilah Soekarno menemukan alasannya untuk mengeluarkan Dekrit Presiden tanggal 5 Juli 1959 yang berisi tiga hal: membubarkan Konstituante, mencabut berlakunya UUDS 1950 dan memberlakukan UUD 1945, dan rencana pembentukan MPRS dan DPAS.

Bagaimanakah keberadaan Dekrit Presiden ini selanjutnya? Sebagian berpendapat bahwa Dekrit Presiden itu merupakan intervensi politik yang sangat tidak konstitusional dan merupakan kudeta, sebab menurut UUDS 1950 yang berlaku ketika itu Presiden tidak berwenang untuk menentukan berlakunya sebuah UUD dan Presiden tidak berwenang membubarkan Konstituante yang merupakan hasil pemilihan umum yang sangat jujur, adil, dan demokratis.

Pandangan tentang Konstituante gagal menjalankan tugasnya menyusun satu konstitusi baru adalah tidak dapat diterima kerena ketika dekrit itu dikeluarkan materi UUD baru sebenarnya hampir selesai dan mencapai sebagian besar kesepakatan tentang masalah-masalah mendasar seperti disebut di atas telah mencapai 90\%. Sebagian kecil yaitu sekitar 10\% yang belum terselesaikan diyakini akan terselesaikan. Dan perbedaan masalah dasar negara yang ketika itu diperdebatkan dalam sidang-sidang Konstituante oleh kedua belah

18 Deliar Noer, Islam Pancasila dan Asas Tunggal, (Jakarta: Yayasan Perkhidmatan, 1983), hal. 9-10. 
pihak yang bersitegang disadari tidak akan melahirkan elaborasi yang khas dalam pasal-pasal konstitusi, sehingga timbul kesadaran tiada gunanya untuk bersitegang masalah dasar negara. Namun ketika kesadaran itu muncul dan telah terjadi kompromi-kompromi yang menjanjikan hasil, keluarlah intervensi Presiden yang berupa Dekrit Presiden 5 Juli 1959. ${ }^{19}$

Adapun mereka yang membenarkan adanya Dekrit ini beralasan dengan konsideran dari dekrit itu sendiri yakni negara dalam keadaan bahaya. Jika negara dalam keadaan bahaya maka Presiden dapat melakukan apa pun untuk menyelamatkan negara karena ada dalil "keselamatan rakyat merupakan hukum yang tertinggi" (salus populasi suprema lex). ${ }^{20}$

Dengan keluarnya Dekrit Presiden 5 Juli 1959 semua sepakat baik terpaksa ataupun dengan kerelaan, masing-masing pihak merasa terikat dengan ketentuan-ketentuan yang terdapat dalam UUD 1945 termasuk di dalamnya Pancasila. Tetapi penyelewengan terhadap kesepakatan ini bisa terjadi dari pihak manapun juga, seperti Gerakan Darul Islam tentu melanggar terhadap UUD 1945, demikian juga pemberontakan lain seperti PRRI/Permesta. Tetapi juga pemerintah melanggar UUD 1945. dan beberapa tahun kemudian, yaitu pada tahun 1966, muncullah Orde Baru dengan tekad melaksanakan Pancasila dan UUD 1945 dengan murni dan konskuen; pertanda bahwa selama pemerintahan Presiden Soekarno ketentuan-ketentuan seperti tertera dalam Pancasila dan UUD 1945 telah dilanggar. ${ }^{21}$

Di bawah pemerintah Soekarno (1959-1966), era rezim yang diawali dengan keluarnya Dekrit Presiden 5 Juli 1959, sebagaimana dijelaskan oleh Yahya Muhaiman yang dikutip Mahfud MD, Dekrit Presiden 5 Juli 1959 telah menjadi gong penutup bagi kehidupan demokrasi parlementer. Sejak dikeluarkan dekrit itu, dimulailah langgam otoritarian dalam kehidupan politik di Indonesia di bawah bendera Demokrasi Terpimpin. Demokrasi Terpimpin mengolah pengambilan keputusan melalui musyawarah mufakat dan berdasarkan semangat gotong-royong. Implikasi sistem ini dijabarkan dalam amanat presiden tanggal 17 Agustus 1959 yang diberi nama Manifesto Politik (Ma-

19 Moh. Mahfud MD, “Politik Hukum Baru Menuju Supremasi Hukum Sebuah Antaran Akademis" dalam Khamami Zada - Idy Muzayyad (ed.), Wacana Politik Hukum dan Demokrasi Indonesia, hal. Xxxi.

20 Deliar Noer, Islam Pancasila Dan Asas Tunggal..., hal. 10.

21 Ibid., hal. 11. 
nipol) yang rinciannya secara sistematis dikenal dengan akronim USDEK. ${ }^{22}$ Demokrasi Terpimpin adalah sistem politik yang hipokrit yang penuh dengan penyimpangan-penyimpangan konstitusional yang disengaja, demi revolusi yang tak kunjung selesai. Namun perlu diingat bahwa demokrasi yang dalam sejarah bangsa kita ini telah menggoreskan suatu episode yang sangat berharga dalam rangka belajar mencari suatu sistem politik demokrasi yang sehat. ${ }^{23}$

Munculnya Demokrasi Terpimpin yang mula-mula dicetuskan oleh partai Murba serta Chairul Saleh dan Ahmadi, ${ }^{24}$ adalah awal dari memudarnya sistem politik demokrasi di negeri ini. Dengan berkembangnya otoritarianisme di bawah Soekarno, maka struktur politik yang dikembangkan adalah struktur politik yang memarginalkan hak-hak dasar warga negara. Sebagai gantinya kekuasaan negara yang kemudian direduksi pada diri seorang Pemimpin Besar Revolusi, cenderung tak terkontrol dan cenderung hegemonik, dengan elite penguasa terdiri dari birokrasi, kelompok nasionalis, komunis dan tentara. Akibatnya, dibuatlah aturan-aturan yang menyimpang dari prinsip-prinsip demokrasi dengan dalih kesatuan dan persatuan. ${ }^{25}$

Selama kurun waktu 1959-1965 Presiden Soekarno dengan sistem Demokrasi Terpimpinnya menjelma menjadi seorang pemimpin yang otoriter. Partaipartai yang marak pada era demokrasi liberal secara praktis lemah dan tak berdaya, kecuali PKI yang dapat memperluas pengaruhnya dengan berlindung di bawah kekuasaannya Soekarno sementara Angkatan Darat dapat memperluas peran dan kekuasaan politiknya. ${ }^{26}$

Seminggu setelah Dekrit Presiden5Juli 1959, Soekarno mengumumkankabinetnya yang baru, menggantikan Kabinet Djuanda yang mengembalikan mandatnya pada 6 Juli. Kabinet Djuanda adalah kabinet peralihan dari Demokrasi Parlementer ke periode Demokrasi Terpimpin. Dalam Kabinet Soekarno ini

${ }_{22}$ Moh. Mahfud MD, Politik Hukum di Indonesia, (Jakarta: PT RajaGrafindo Persada, 2009), hal. 136.

23 A. Syafii Maarif, Islam dan Politik di Indonesia pada Masa Demokrasi Terpimpin (19591965), hal.131-132.

24 Moh. Mahfud MD, Politik Hukum di Indonesia...., hal.137.

25 Muhammad AS. Hikam, "Politik Hukum di Indonesia dalam Konteks Reformasi dan Demokrasi", dalam Khamami Zada - Idy Muzayyad (Ed.), Wacana Politik Hukum dan Demokrasi Indonesia, hal. 8.

26 Moh. Mahfud MD, Politik Hukum di Indonesia...., hal.137. 
Djuanda tetap kemudian diberi posisi penting, yaitu sebagai Menteri Pertama yang tugasnya tidak banyak berbeda dengan tugas Perdana Menteri. Kabinet baru di bawah payung UUD 1945 ini diberi nama Kabinet Kerja. Kabinet inilah nanti yang bertugas melaksanakan gagasan Soekarno dalam bentuk Demokrasi Terpimpin. Demokrasi gaya baru ini telah membawa Soekarno ke puncak kekuasaannya yang memang sudah lama dia dambakan. Tetapi karena fondasinya tidak kokoh, sistem itu pulalah yang pada akhirnya membawa Presiden pertama Indonesia itu ke jurang kehancuran politik untuk selama-lamanya. Dia terkubur bersama sistem yang diciptakan, sekalipun jasanya dalam pergerakan kemerdekaan dan penciptaan kesatuan bangsa tidak akan dilupakan orang. Sekitar enam setengah tahun sistem ini beroperasi dalam sejarah kontemporer Indonesia, secara politik umat Islam berbeda pandangan, berpecah-belah berhadapan dengan sistem yang diciptakan Soekarno itu. Pilihan untuk turut atau tidak turut dalam suatu sistem kekuasaan telah membelah umat ini menjadi dua kubu yang saling berhadapan, sedangkan posisi politik mereka secara nasional sudah tidak diperhitungkan orang lagi. ${ }^{27}$

Dalam membaca politik umat Islam pada era Demokrasi Terpimpin, antara satu pengamat dengan pengamat yang lainnya ada perbedaan dan keragaman pandangan. Salah satu bacaan terhadap kondisi hubungan umat Islam dan negara pada saat itu bahwa umat Islam dalam mensikapinya secara garis besar terdiri atas dua kelompok.

Kelompok pertama Masyumi memandang bahwa ikut serta dalam suatu sistem politik otoriter sebagai penyimpangan dari ajaran Islam. Di mata Masyumi sistem Demokrasi Terpimpin akan membawa bencana bagi bangsa dan Negara. Oleh sebab itu gerakan Soekarno harus dilawan, apapun akibatnya. Semangat inilah yang diistilahkan idealism martir Masyumi yang punya resiko politik jauh bagi golongan modernis Muslim di Indonesia. Masyumi sebagai cagar demokrasi tampaknya tidak punya pilihan lain kecuali menghadapi Soekarno dan sistemnya, sekalipun dengan sisa-sisa tenaga yang tidak seimbang. Harapan Masyumi bahwa rakyat tidak akan berpihak kepada demokrasi otoriter, ternyata sia-sia. Sementara itu PKI yang sangat lihai dalam memanipulasi politik pada waktu berpihak sepenuhnya kepada sistem Soekarno. Dan orang pun semua tahu bahwa salah satu tujuan dari taktik PKI adalah untuk

27 A. Syafii Maarif, Islam dan Politik ..., hal.49-50. 
menghancurkan lawan-lawan politiknya, dan yang terbesar adalah Masyumi. Pada masa Demokrasi Terpimpin, jargon politik PKI tentang "kepala batu" sudah menyatu dengan jargon politik Soekarno yang juga menilai Masyumi sebagai kekuatan "kepala batu" yang merintangi penyelesaian revolusi Indonesia. Menurut logika ini, golongan modernis khususnya Masyumi tidak patut lagi hidup pada era Demokrasi Terpimpin ${ }^{28}$ dan di mata Soekarno sebagaimana dinyatakan oleh Mohammad Roem dan dikutip oleh Syafii Maarif bahwa Masyumi dan pemimpin-pemimpinnya dimasukkan dalam kategori musuh revolusi dan karena itu harus disingkirkan. ${ }^{29}$

Setelah Demokrasi Terpimpin berjalan sekitar sembilan bulan, Soekarno membubarkan parlemen hasil Pemilihan Umum 1955 pada tanggal 20 Maret 1960, kemudian ia membentuk Dewan Perwakilan Rakyat Gotong Royong (DPRGR). Dalam pembentukan DPRGR ini Masyumi tidak diikutsertakan karena merupakan partai penghalang revolusi dan ditambah lagi dengan tuduhan sebagai partai yang mendalangi pemberontakan PRRI-Permesta, ${ }^{30}$ sekalipun secara hukum tuduhan itu tidak beralasan, dan karena itu pada waktu pembentukan DPRGR, sebenarnya nasib Masyumi sudah terbayang sekalipun belum dapat dipastikan benar. $^{31}$

Ketidakharmonisan Masyumi dengan pemerintah atau Soekarno pada saat itu tidak dapat lepas dari perbedaan pandangan atau pendapat antara Natsir (tokoh Masyumi) dengan Soekarno dalam menghadapi masalah Irian Barat. Sikap Kabinet Natsir dan Soekarno dalam masalah Irian Barat inilah yang kemudian menjadi titik awal dari "iklim patah arang" antara kedua figur republik ini, karena hasil pemungutan suara terhadap masalah ini adalah 5 untuk Soekarno dan 12 untuk Natsir. Bagi Soekarno sebagai figur puncak waktu itu tidak dapat menerima kekalahan suara seperti yang terjadi dalam sidang kabinet itu. ${ }^{32}$

28 Ibid., hal. 57-58.

29 Ibid. hal. 59.

${ }^{30}$ Menurut Diliar Noer, Masyumi pada permulaan tahun 1958 mengeluarkan pernyataan bahwa baik PRRI maupun pemerintah Soekarno telah melanggar Undang-Undang Dasar, (Diliar Noer, Islam Pancasila..., hal. 11)

\footnotetext{
${ }^{31}$ A. Syafii Maarif, Islam dan Politik di Indonesia..., hal. 61.

${ }^{32}$ Ibid., hal. 74-75.
} 
Kelompok kedua, Liga Muslim (NU, PSII ${ }^{33}$ dan PERTI) turut serta dalam Demokrasi Terpimpin adalah sikap realistik dan pragmatik, dalam hal ini NU berdalil dengan Kaidah Ma la yudraku kulluhu la yutraku ba'duhu (apa yang tidak dapat diraih seluruhnya, jangan dilepaskan sebagian yang dapat diraih). Dengan dalil ini maka NU memutuskan untuk masuk dalam sistem Demokrasi Terpimpin, meskipun kecil keuntungan yang dapat diraih. Liga Muslim, di mata PKI, sekalipun juga musuh tetapi tidak sesukar menghadapi kekuatan "kepala batu" karena sejak awal beberapa bulan sebelum Dekrit 5 Juli 1959 NU menunjukkan sikap positif terhadap Demokrasi Terpimpin. Pada tanggal 11 Januari 1959, Presiden Soekarno mengadakan pertemuan dengan partai-partai. NU diwakili oleh Wahab Chasbullah, Idham Chalid, Djamaluddin Malik dan Zainul Arifin. Ketika ditanya tentang sikap NU terhadap Demokrasi Terpimpin, Zaenul Arifin menjawab ..."semua orang tahu pendirian NU, yaitu setuju dengan demokrasi yang dipimpin oleh hikmah kebijaksanaan musyawarah". Dari jawaban ini jelas menunjukkan sikap politik NU ikut serta dalam sistem yang hendak diciptakan.

Dalam waktu yang hampir bersamaan di rumah Anwar Tjokroaminoto pada tanggal 4 Januari 1959 diadakan pertemuan antara Liga Muslimin, Masyumi dan PPTI (Partai Persatuan Tarekat Indonesia). Hasil pertemuan itu adalah bahwa mereka bersepakat memperjuangkan Islam sebagai dasar negara melalui konstituante. Dalam masalah-masalah mendasar Masyumi masih ikut dalam kelompok Liga Muslimin, tetapi dalam urusan Demokrasi Terpimpin, jalan yang ditempuh sudah bersibak dua. ${ }^{34}$

Catatan lain yang juga menarik adalah pernyataan NU bahwa penerimaan eksistensi DPRGR adalah dalam rangka menegakkan prinsip amar ma`ruf nahi munkar. Dalam arti praktis yang dituju NU adalah bertambahnya jumlah wakil umat Islam dalam DPRGR. Secara keseluruhan hingga sebanding dengan wakil-wakil golongan lainnya, tetapi kenyataan wakil golongan Islam menunjukkan lain justru berkurang bahwa pada DPR pilihan rakyat sebanyak 115 kursi (Masyumi 57 kursi, NU. 45 kursi, PSII. 8 kursi, PERTI 4 kursi, dan PPTI 1 kursi),

${ }^{33}$ Bila dilihat dari sudut faham keagamaan di Indonesia, PSII termasuk kelompok modernis. Ibid., hal. 59.

34 Ibid., hal. 60-61 
sedang dalam DPRGR wakil golongan Islam hanya 67 kursi sementara golongan nasionalis sekuler 94 kursi dan komunis 81 kursi. ${ }^{35}$

Pada periode ini menurut Syafii Maarif, partai-partai Islam memiliki peran pinggiran atau bukan peran utama. Peran utama pada Demokrasi Terpimpin adalah Soekarno, Angkatan bersenjata, dan PKI. Golongan Islam hanyalah untuk meramaikan jargon Nasakom (Nasional, Agama, dan Komunis), suatu bentuk kerjasama semu dan dipaksakan. ${ }^{36}$

Pada periode ini hingga tahun 1965 kekuatan umat Islam atau partai-partai Islam terbelah menjadi dua, yaitu pertama partai-partai Islam (Liga Muslim) yang berkolaborasi dengan Soekarno yang dimotori oleh NU, dan yang kedua Masyumi yang pada tahun 1960 diperintahkan untuk membubarkan diri. Strategi yang dilakukan oleh kelompok pertama adalah tidak lepas dari pengaruh pesantren dalam arti konservatisme Islam, suatu budaya warisan Islam klasik yang telah mendorong lahirnya kelompok ini. Dalam partai ini pengaruh kiai demikian besarnya, hingga hampir-hampir tanpa batas, ${ }^{37}$ bahkan menjadi penghubung antara Islam tradisional dengan dunia nyata. ${ }^{38}$ Demikian ini sesuai dengan karakter dari pesantren. Karakter pertama yang ada di dunia pesantren pada umumnya dan pesantren yang berada di bawah pengaruh NU khususnya, otoritas kiai begitu dominan dan sangat dihormati. ${ }^{39}$ Karakter kedua adalah sikap curiga pesantren terhadap orang-orang luar, sikap ini mengandung fenomena sosiologis, yaitu adanya sifat tertutup pesantren, dan

35 Ibid., hal. 62 dan secara rinci komposisi DPR berdasarkan hasil Pemilu 1955 dapat dilihat pada Moh. Mahfud MD, Politik Hukum di Indonesia...., hal. 91..

36 A. Syafii Maarif, Islam dan Politik di Indonesia pada Masa Demokrasi Terpimpin...., hal. 64, bandingkan dengan Douglas E. Ramage, Politics in Indonesia Democracy, Islam and the Ideologi of Tolerance, (London and New York: Routledge, 1995), hal. 19.

37 Saifuddin Zuhri misalnya dalam menggambarkan Kiai Wahab Chasbullah dalam perjalanan NU sebagai peran yang sangat besar. Ibid. hal. 86.

38 Zamakhsyari Dhofier, Tradisi Pesantren: Studi tentang Pandangan Hidup Kiai, (Jakarta: LP3ES, 1974), hal. 42-43.

39 Kiai dan para pembantunya di lingkungan pesantren merupakan hirarki kekuasaan satu-satunya yang diakui, karena kiai punya otoritas moral yang besar di kalangan para santri, maka kekuasaannya adalah mutlak. Para santri rasanya merasa terikat dengan kiainya sepanjang hidupnya, setidak-tidaknya sebagai sumber inspirasi dan bantuan moral bagi kehidupan mereka. (Abdurrahman Wahid, Pesantren: Studi tentang Pandangan Hidup Kiai [Jakarta: LP3ES, 1982], hal. 177.) 
di sisi lain berkembangnya solidaritas yang tinggi antarpesantren tradisional, ${ }^{40}$ yang ini oleh Syafii Maarif dipandang sebagai sebuah solidaritas defensife, dan ini hanya mungkin dapat bertahan dalam suatu masyarakat agraris yang belum dilanda oleh arus komunikasi yang pesat seperti pada akhir abad ke-20, ${ }^{41}$ dan tentunya bagaimana kenyataan pada abad ke-21 seperti sekarang.

Tradisi sebagaimana tersebut di atas terimplentasi dalam kehidupan perpolitikan NU di era Demokrasi Terpimpin, semisal masuknya NU ke DPRGR adalah karena ada kata putus dari Kiai Abdulwahab Chasbullah sebagai Rais 'Am NU. Sebagaimana sudah diketahui bahwa sebelumnya telah terjadi gesekan-gesekan yang ditunjukkan oleh sementara pemimpin wilayah NU terhadap gerakan politik NU di DPRGR, suara menentang itu makin lama makin redup dan akhirnya lenyap dari peredaran dengan otoritas Kiai Wahab yang telah memberikan kata putus. ${ }^{42}$

Konsep politik yang digunakan oleh NU, menurut Syafii Maarif adalah paternalistik yang merupakan bagian penting dari subkultur Jawa tentang hubungan "bapak-anak" dalam sebuah keluarga besar bangsa Indonesia. Dalam terma Soekarno, konsep bapak adalah seorang 'tetua' yang serba bijak, yang tidak mendiktatori tapi memimpin dan mengayomi. Dengan beberapa perbedaan, sebenarnya subkultur pesantren juga sangat paternalistik, di situ posisi kiai dipandang begitu besar secara spiritual. Pada masa Demokrasi Terpimpin, Soekarno adalah sesepuh bangsa Indonesia secara keseluruhan, sementara dalam kubu NU, Kiai Abdulwahab Chasbullah dan Kiai Idham Chalid adalah figur-figur puncak yang menentukan secara mutlak warna politik NU. Kiai Abdulwahab Chasbullah sebagai Syuriyah yang bertugas untuk mencari pembenaran agama terhadap putusan politik yang diambil NU, sedangkan Kiai Idham Chalid sebagai Tanfiziyah adalah pelaksana praktis dari keputusan-keputusan yang telah dibenarkan Syuriyah untuk dijalankan partai ini. ${ }^{43}$

Dalam merespon sistem Demokrasi Terpimpin strategi yang digunakan oleh NU dengan menggunakan pertimbangan pragmatis-realistis, seperti yang dituturkan oleh Syafii dalam wawancaranya dengan K.H.A. Syaichu bahwa

\footnotetext{
40 Ibid., hal. 45.

${ }^{41}$ A. Syafii Maarif, Islam dan Politik di Indonesia pada Masa Demokrasi Terpimpin..., hal. 88.

${ }^{42}$ Ibid., hal. 90-91.

43 Ibid., hal. 93.
} 
dalam menghadapi Demokrasi Terpimpin umat Islam Indonesia punya dua macam ijtihad politik yang berbeda. Ijtihad pertama bahwa umat Islam lebih baik masuk ke dalam sistem itu demi kepentingan Islam, sedangkan ijtihad kedua bahwa demi kepentingan Islam maka umat Islam harus melawan sistem itu. Dari dua ijtihad di atas dipilih bentuk yang pertama, yang demikian terlihat jelas dari pernyataan K.H. Muslich bahwa Demokrasi Terpimpin tidak menyalahi demokrasi yang dianut oleh agama Islam, karena agama Islam tidak menganut demokrasi awur-awuran, melainkan Demokrasi Terpimpin, menurut ajaran Islam. Oleh karena itu bagi NU tidak diragukan lagi bahwa turut serta dalam jaringan kekuasaan sentral sistem politik Soekarno adalah atas dasar pertimbangan dan untuk kepentingan agama. ${ }^{44}$

Posisi politik partai-partai Islam umumnya dan NU khususnya dianggap revolusioner karena secara formal dapat kerjasama dengan nasionalis, agama dan komunis (Nasakom). Kemudian pertimbangan politik apakah sesuatu kekuatan politik dianggap revolusioner atau kontra revolusioner adalah ditentukan oleh sikapnya terhadap Nasakom. Semakin vokal sebuah kekuatan politik terhadap Nasakom berarti semakin kuat dukungan terhadap Soekarno, dan konskuensi lebih lanjut tidak perlu cemas akan tersingkir dari logika Revolusioner Soekarno, dan yang demikian yang dilakukan oleh NU sebagai kekuatan politik terbesar pada saat itu, dengan asumsi bahwa berada di dalam akan lebih baik ketimbang berada di luar.

Dijelaskan oleh Deliar Noer, NU pada awalnya sebagai organisasi agama kemudian menjadi partai politik, ia radikal dan revolusioner dalam tahun-tahun 1945-1950, tetapi dalam masa sebelum perang ia lebih bersifat evolusioner. Pada waktu sebelum perang ia tidak langsung turut berpolitik, ia berpolitik melalui Majlis Islam A`la Indonesia. Secara langsung NU lebih memberikan perhatian pada soal pendidikan dan agama (dalam arti sempit). Bersama dengan partaipartai Islam lain berjuang dalam Konstituante (1956-1959), dan memperjuangkan Piagam Jakarta dalam memenuhi himbauan Soekarno untuk kembali ke UUD 1945 pada tahun 1959. Tetapi kemudian, dengan kian meningkatnya peranan PKI serta kekuasaan Soekarno sehingga suasanapun memperlihatkan pada Presiden ketika itu, NU dan partai-partai lain membiarkan Masyumi dan PSI dibubarkan (atau bubar atas perintah Presiden), dan bersama-sama dengan partai lain,

44 Ibid., hal. 94-95. 
termasuk PKI menyuarakan semangat Nasakom. Kebangkitan Orde Baru menampilkan NU dengan identitas yang lain: pemuda NU yang bergabung dalam Pemuda Ansar turut aktif melakukan pembersihan PKI dan antek-anteknya. ${ }^{45}$

\section{Gerakan Politik Islam pada Era Orde Baru}

Dalam perkembangannya rezim Demokrasi Terpimpin (1959-1966) yang kemudian disebut Orde Lama ternyata tak mampu bertahan dari goncangan yang disebabkan oleh maraknya konflik politik di tingkat elit (Presiden Soekarno, Angkatan Darat dan PKI) yang saling bersaing, Soekarno bertindak sebagai penyeimbang antara dua kekuatan lainnya. Ditambah dengan krisis ekonomi yang menimpa seluruh bangsa dan nyaris ambruk. ${ }^{46}$ Puncak elit tersebut adalah peristiwa G-30-S/PKI yang menumbangkan rezim Demokrasi Terpimpin serta meretas bagi peralihan kekuasaan dan pemerintahan Orde lama ke Orde Baru ditandai dengan turunnya Soekarno dari kursi kepresidenan pasca kudeta G30-S/PKI pada tahun 1965.

Lahirnya Orde Baru didukung oleh kalangan pelajar dan mahasiswa yang tergabung dalam Pemuda dan Pelajar Indonesia (KAPPI) dan Kesatuan Aksi Mahasiswa Indonesia (KAMI). Kesatuan Aksi yang dibentuk pada tanggal 25 Oktober 1965 mengetengahkan Tri Tuntutan Rakyat (TRITURA) dan Tuntutan Hatinurani Rakyat (TUNHANURA). Melalui kegiatan politik yang banyak mempergunakan kegiatan fisik berupa demonstrasi, dan ini mereka lakukan karena terdapat situasi anomi di dalam masyarakat, ${ }^{47}$ bersama ormas-ormas onderbouw partai-partai politik yang lemah pada zaman Demokrasi Terpimpin yang semuanya didukung oleh Angkatan Darat. Akhirnya Soekarno mengeluarkan Surat Perintah Sebelas Maret (Supersemar) 1966 yang ditujukan kepada Soeharto untuk:

Pertama mengambil segala tindakan yang dianggap perlu, untuk terjaminnya keamanan ketenangan serta kestabilan jalannya pemerintahan dan jalannya revolusi, serta menjamin keselamatan pribadi dan kewibawaan Pemimpin/Presiden/Panglima Tertinggi/Pemimpin

45 Deliar Noer, Islam Pancasila dan Asas Tunggal...., hal. 48-49.

46 Mohtar Masoed, Ekonomi dan Struktur Politik Orde Baru 1966-1971 (Jakarta LP3ES, 1989), hal. 45-47.

47 Arbi Sanit, Sistem Politik Indonesia Kestabilan Peta Kekuatan Politik Dan Pembangunan, (Jakarta: CV Rajawali, 1987), hal.100-101. 
Besar Revolusi/Mandataris MPRS demi untuk keutuhan Bangsa dan Negara Republik Indonesia, dan melaksanakan dengan pasti segala ajaran Pemimpin Besar Revolusi. Kedua, mengadakan koordinasi pelaksanaan perintah dengan panglima-panglima angkatan-angkatan lain dengan sebaiknya. Ketiga, supaya melaporkan segala sesuatu yang bersangkut-paut dalam tugas dan tangung jawabnya seperti tersebut di $\operatorname{atas.}^{48}$

Surat perintah tersebut telah menjadi alat legitimasi yang sangat efektif khususnya bagi Angkatan Darat untuk melangkah lebih jauh dalam panggung politik yang dipimpin oleh Soeharto. Terlebih lagi setelah bulan Juni 1966 DPR-GR mengeluarkan sebuah Memorandum yang memuat usul tentang Sumber Tertib Hukum, Tata Urutan Perundang-undangan, dan skema Susunan Kekuasaan menurut UUD 1945. Memoradum ini, khusus mengenai Sumber Tertib Hukum dan Tata Urutan Perundang-undangan, diterima dalam Sidang Umum MPRS IV yang berlansung bulan Juli 1966 dan dijadikan Lampiran Otentik Ketetapan MPRS No. XX/MPRS/1966. Dengan diterimanya memorandum ini, maka kedudukan Soeharto sebagai tokoh utama dalam pemerintahan semakin kuat karena dalam memorandum itu disebutkan Supersemar sebagai dasar hukum bagi lahirnya Orde baru di bawah pimpinan Soeharto. ${ }^{49}$

Pada awal Orde Baru banyak dilakukan perubahan terhadap kecenderungan birokrasi yang tidak bertanggungjawab warisan Orde Lama. Rezim inilah yang kemudian dalam kurun waktu lebih dari tiga dasa warsa mencoba menegakkan sebuah sistem politik otoriter dengan nama Demokrasi Pancasila, dan secara prinsipil, sistem politik yang ditegakkan oleh Soeharto ini tidaklah begitu berbeda dengan Demokrasi Terpimpin. Bahkan Menurut Mokhtar Pabotinggi sebagaimana dikutip oleh AS Hikam bahwa Orde Baru adalah murid dan pelaksana terbaik dari konsep Demokrasi Terpimpin, tentu saja ada perbedaan yang cukup mendasar dalam hal landasan sistem ekonomi kedua rezim ini.

Pada Demokrasi Terpimpin Soekarno mencoba menegakkan sistem otoriter dengan basis ekonomi sosialistik, maka Soeharto mencoba menegakkan sistem otoriter kapitalistik melalui pembangunan ekonomi yang berkesinambungan. Pada Demokrasi Terpimpin, elite penguasa terdiri dari birokrasi, kelompok na-

\footnotetext{
48 Moh. Mahfud MD, Politik Hukum di Indonesia...., hal. 196-197.

49 Ibid., hal. 198.
} 
sionalis, komunis dan tentara, maka di bawah Orde Baru elite penguasa terdiri dari militer, birokrat, teknokrat dan pemilik modal nasional, ${ }^{50}$ dengan memakai format politik yang berporos pada eratnya hubungan militer dan teknokrat untuk tujuan melaksanakan pembangunan dan mewujudkan pemerintah yang stabil dan kuat. Kekuatan militer dan birokrasi merupakan mesin politik untuk menata kehidupan sosial dan politik masyarakat, sehingga Orde Baru melalui dua komponen tersebut menjadi kekuatan politik tunggal di Indonesia. ${ }^{51}$

Sejak kemunculan Orde Baru selalu mengklaim dirinya sebagai rezim yang melaksanakan UUD 1945 dan Pancasila secara murni dan konskuen dan menginginkan koreksi total terhadap segala bentuk penyelewengan dan penyimpangan terhadap keduanya yang dilakukan oleh rezim Orde Lama. Karena itu Orde Baru diartikan sebagai tatanan politik dan masyarakat Indonesia yang didasarkan pada pelaksanaan UUD 1945 dan Pancasila secara murni dan konsekuen. Secara rinci pengertian Orde Baru sebagaimana yang dirumuskan dalam Seminar II Angkatan Darat adalah sebagai berikut:

1. Musuh utama Orde Baru adalah PKI/pengikut-pengikutnya atau Orde Lama.

2. Orde Baru adalah suatu sikap mental

3. Tujuan Orde Baru adalah menciptakan kehidupan politik, ekonomi, dan kultural yang dijiwai oleh moral Pancasila, khususnya sila Ketuhanan Yang Maha Esa.

4. Orde Baru menghendaki pemikiran yang lebih realistis dan pragmatis, walaupun tidak meninggalkan idealisme perjuangan.

5. Orde Baru menghendaki diutamakannya kepentingan nasional, walaupun tidak meninggalkan komitmen ideologi perjuangan anti imperialisme dan kolonialisme.

6. Orde Baru menginginkan suatu tata susunan yang lebih stabil, berdasarkan lembaga-lembaga (misalnya: MPRS, DPR, Kabinnet dan Musyawarah) dan yang kurang dipengaruhi oleh oknum-oknum yang dapat menimbulkan kultus individu; akan tetapi Orde Baru tidak menolak pimpinan yang

${ }^{50}$ Muhammad AS. Hikam, "Politik Hukum di Indonesia dalam Konteks Reformasi dan Demokrasi", dalam Khamami Zada - Idy Muzayyad (Ed.),Wacana Politik Hukum dan Demokrasi Indonesia...., hal. 8-9.

51 Lance Castle, Birokrasi dan Masyarakat Indonesia, (Surakarta: Hapsara, 1983), hal. 27. 
kuat dan pemerintahan yang kuat, malahan menghendaki ciri-ciri yang demikian dalam masa pembangunan.

7. Orde Baru menghendaki pengutamaan konsolidasi ekonomi dan sosial dalam negeri.

8. Orde Baru menghendaki pelaksanaan yang sungguh-sungguh dari cita-cita demokrasi politik dan demokrasi ekonomi.

9. Orde Baru menghendaki suatu tata politik dan ekonomi yang berlandaskan Pancasila, UUD 1945, dan yang mempunyai prinsip idiil, opersional dalam ketetapan MPRS IV/1966.

10. Orde Baru suatu tata politik dan ekonomi yang belum mempunyai kenyataan, yang ada baru suatu iklim yang cukup menguntungkan bagi pertumbuhan Orde Baru ini.

11. Orde Baru adalah suatu proses peralihan dari Orde Lama ke suatu susunan baru.

12. Orde Baru masih menunggu pelaksanaan dari segala Ketetapan MPRS IV/1966.

13. Orde Baru harus didukung oleh tokoh pimpinan yang berjiwa Orde Baru yang menduduki tempat-tempat yang strategis.

14. Orde Baru harus didukung oleh suatu imbangan kekuatan yang dimenangkan oleh barisan Orde Baru. ${ }^{52}$

Dari sejumlah rumusan di atas ada beberapa kata kunci yang kemudian menentukan konfigurasi format politik rezim Orde Baru, yaitu: konsolidasi ekono$\mathrm{mi}$, pimpinan dan pemerintahan yang kuat, dan susunan yang stabil..$^{53}$ Maka selanjutnya format politik yang diciptakan oleh rezim Orde Baru ini antara lain: pertama, peranan birokrasi sangat kuat karena dijalankan oleh militer setelah ambruknya demokrasi terpimpin, sehingga ia menjadi satu-satunya pemain utama di pentas politik nasional. Kedua, upaya membangun sebuah kekuatan organisasi sosial politik sebagai perpanjangan tangan ABRI dan pemerintah dalam wujud lahirnya Golkar sebagai mayoritas tunggal organisasi politik di masa Orde Baru. Ketiga, penjinakan radikalisme dalam politik melalui proses depolitisasi massa, seperti menerapkan konsep floating mass dan NKK/BKK di lingkungan pendidikan tinggi. Keempat, lebih menekankan pendekatan keamanan (security approach)

${ }^{52}$ Moh. Mahfud MD, Politik Hukum di Indonesia...., hal. 199-200.

53 Ibid. 
dan pendekatan kesejahteraan (welfare approach) dalam pembagunan sosial politik. Kelima, menggalang dukungan masyarakat melalui organisasi-organisasi sosial dan kemasyarakatan yang berbasis korporatis. ${ }^{54}$

Kebijakan-kebijakan politik pemerintah Orde Baru terhadap gerakan umat Islam atau hubungan Islam dan negara dapat dipolakan menjadi beberapa pola hubungan. Menurut Bahtiar Effendi hubungan Islam dan negara dapat dilihat dari lima teori. Pertama, teori dekonfensionalisasi, yaitu teori yang memiliki pandanganbahwasemuakelompokIslammenerimaPancasila. Keduadomestikasi Islam dari Harry J. Benda. Dalam pandangannya politik Islam dicengkeram oleh budaya dan orang Jawa. Ini berdasarkan catatan sejarah sejak abad 18 sampai saat ini. Ketiga, skismatik dan aliran berdasarkan penelitian Robert R Jay dan Clifford Geertz. Menurutnya Islam dan Jawa mengalami persaingan dalam bidang politik budaya dan sosial. Keempat, trikotomi dari Allan Samson yaitu pembagian politik Islam kepada fundamentalis, reformis dan akomodasionis. Menurutnya Islam juga mampu bekerja sama dalam bidang sosial ekonomi sebagai prioritas kegiatan mereka. Kelima, Islam kultural dari Donald K. Emmerson. Dalam kacamatanya Islam telah masuk dalam struktrual, legislatif dan juga kultural atau yang lebih dikenal sebagai infrastruktural. ${ }^{55}$ Menurut Abdul Azis Thaba hubungan Islam dan negara ada tiga pola hubungan, yaitu hubungan antagonistik, resiprokal kritis, dan akomodatif. ${ }^{56}$

54 Affan Gaffar, Politik Indonesia: Tradisi Menuju Demokrasi, (Yogyakarta: Pustaka Pelajar, 1999), hal. 37. dan Abdul Azis Thaba, Islam dan Negara ..., hal. 239-289.

55 Bahtiar Effendy, Islam dan Negara: Transformasi Pemikiran dan praktis Politik islam di Indonesia, (Jakarta: Paramadina, 1998.) hal. 30-45.

56 Abdul Azis Thaba, Islam dan Negara dalam Politik Orde Baru..., hal. 26-30. Menurut Aminuddin, hubungan politik umat Islam dengan negara atau kekuasaan dapat depetakan menjadi sebagai berikut: (1) strategi akomodatif -justifikasi terhadap kekuasan negara yang sering tidak mencerminkan idealisme Islam dengan konskuensi menerima penghujatan dari garis keras Islam, (2) strategi isolatif-opposisional, yaitu strategi menolak dan memisahkan diri dari kekuasaan negara untuk membangaun kekuatan sendiri, dengan konsekuensi kehilangan faktor pedukungnya, yaitu kekuaan negara itu sendiri yang kemudian dikuasai dan dimanfaatkan oleh orang lain.(3). strategi integratif-kritis, yaitu memisahkan diri dari kekuasaan negara tetapi tetap kritis terhadap penyelewengan kekuasaan dalam suatu perjuangan dari dalam, tetapi strategi ini sering berhadapan dengan hegemoni negara itu sendiri, sehingga efektivitas perjuangannya dipertanyakan. (Aminuddin, Kekuatan Islam, Pergulatan Kekuasaan di Indonesia, [Yogyakarta: Pustaka Pelajar, 1999], hal. 21-22.) Menurut Azyumardi Azra perdebatan itu telah berlangsung sejak hampir satu abad, dan berlang- 


\section{a. Masa Bulan Madu (1966-1969)}

Dalam periode awal konsolidasi pemerintahan Orde Baru optimisme di kalangan umat Islam khususnya dan masyarakat luas pada umumnya akan kehidupan demokrasi karena romantisisme perjuangan menumbangkan Orde Lama penuh dengan retorika demokrasi. Tiga tahun awal dari pemerintahan rezim ini menampakkan corak yang cukup demokratis, yang ditandai dengan kehidupan pers yang relatif bebas, produk-produk MPRS yang penuh dengan komitmen atas demokrasi, HAM dan hukum, dan sebagainya. Tetapi setelah itu sekitar tahun 1968 hubungan politik antara pemerintah dan umat Islam telah terbuka dengan jelas adanya suatu ketegangan. ${ }^{57}$

Orde Baru dimulai dengan penuh harapan oleh kalangan yang tidak suka dengan kepemimpinan Soekarno. Heroisme dalam menumbangkan yang lama, dan menumbuhkan yang baru, tercermin dalam demonstrasi, dan perlawanan yang sering secara keras dilakukan terhadap para pembela Presiden Soekarno termasuk pengawal istana Cakrabirawa dan barisan pemuda yang dibentuk wakil perdana menteri Soebandrio, serta berbagai kesatuan PKI. Dalam keadaan seperti ini siapa pun yang tampil mendapat sambutan hangat dan penuh harap. ${ }^{58}$

Praktis pada permulaan Orde Baru ada dua usaha dari kalangan umat Islam, berpacu dengan pendukung lain Orde Baru untuk mengisinya. Pertama

sung hingga dewasa ini. Ketegangan perdebatan tersebut diilhami oleh hubungan yang agak canggung antara Islam sebagai agama (din) dan negara (daulah). Terdapat tiga paradigma tentang hubungan agama dan negara yaitu integralistik, simbiotik dan sekularistik. Paradigma integralistik merupakan paham dan konsep yang menganggap bahwa agama dan negara merupakan satu kesatuan yang tidak dapat dipisahkan. Keduanya merupakan lembaga yang menyatu (integrated). Ini juga memberikan pengertian bahwa negara merupakan suatu lembaga politik sekaligus lembaga agama. Dari sinilah kemudian dikenal paham Islam: din wa daulah, yang sumber hukum positifnya adalah hukum agama. Paradigma ini dianut oleh kelompok Islam Syi'ah. (Azyumardi Azra, Pergolakan Politik Islam, [Jakarta: Paramadina, 1996], hal. 1. ) Menurut M. Imam Aziz hubungan Islam dengan kekuasaan terdiri dari dua bentuk, yakni hubungan yang bersifat antagonistik dan hubungan yang bersifat akomodatif. (Imam M. Aziz, Agama, Demokrasi dan Keadilan, [Jakarta: PT. Gramedia Pustaka Utama, 1993], hal. 105.)

57 Moh.Mahfud MD, "Konfigurasi Politik dan Hukum Pada Era Orde Lama dan Orde Baru"...., hal. 24.

58 Deliar Noer," Islam dan Politik: Mayoritas atau Minoritas", dalam Prisma, Nomor 5, Tahun XVII, 1988, hal. 14. 
adalah usaha rehabilitasi Masyumi. Tokoh-tokoh Masyumi dengan berbagai saluran memperjuangkan supaya tokoh-tokoh yang masih dalam tahanan segera dibebaskan dan Partai Masyumi direhabilitasi. Di zaman rezim Soekarno berkuasa, partai ini dan tokoh-tokohnya memang ditekan keras, dan menderita. Setelah bubar suara mereka masih tetap terhimpun secara informal dan pada tanggal 24 Oktober 1966 di muka keluarga besar Bulan Bintang, Prawoto Mangkusasmito, Ketua Umum partai waktu dibubarkan, berpidato soal rehabilitasi partai ini, meski dia sadar bahwa permintaan itu tidak akan gampang terkabulkan begitu saja karena masih ada keberatan di lingkungan ABRI, dan ini terasakan dalam pidatonya namun dia tetap bersemangat karena adanya berbagai dukungan. ${ }^{59}$

Rasa optimis ini pudar setelah pernyataan ABRI bulan Desember 1966, bahwa sikap ABRI tentang partai-partai terlarang PKI dan juga Masyumi yang dianggap pernah menyelewengkan Pancasila dan UUD 1945. Prawoto mengirimkan suarat kepada Ketua Presidium Kabinet, Jendral Soeharto tanggal 22 Desember 1966, yag menyatakan rasa kebertan status Masyumi yang membubarkan diri (bukan dibubarkan) disamakan dengan PKI. Surat tersebut dijawab Jendral Soeharto pada tanggal 6 Januari 1967, dalam butir nomor 7 disebutkan bahwa "alasan-alasan yuridis, ketatanegaraan dan psikologi telah membawa ABRI pada satu pendirian bahwa ABRI tidak dapat menerima rehabilitasi bekas partai politik Masyumi." Namun demikian hak-hak politik anggota Masyumi dijamin. ${ }^{60}$

Menghadapi jalan buntu ini, tokoh-tokoh Masyumi bersama dengan berbagai organisasi Islam, budayawan dan muslim Cina mendirikan forum yang namanya Badan Koordinasi Amal Muslimin (BKAM) yang dipimpin oleh Letnan Jendral Sarbini dan salah seorang pendirinya adalah Jendral A.H. Nasution. Organisasi ini didirikan untuk menghimpun organisasi Islam yang belum punya induk partai. Selanjutnya forum ini membuat Panitia 7 yang terdiri dari tokoh-tokoh Islam, mereka itu seperti bekas Ketua Masyumi K.H. Faqih Usman, Sekretaris Agus Sudono dengan anggota Hasan Basri, Anwar Haryono, E.Z. Muttaqien, Marzuki Jatim, dan Ny. Sjamsuridjal. Panitia tersebut bertu-

59 Nasir Tamara, "Sejarah Politik Islam Orde Baru”, dalam Prisma, Nomor 5, Tahun XVII, 1988, hal. 42-43.

60 Ibid. 
gas untuk menyiapkan sebuah partai baru yang dinamakan Partai Muslimin Indonesia. Bagi sebagian umat Islam partai ini diharapkan sebagai pengganti Masyumi, sedang bagi pemerintah partai ini harus menjadi sebuah partai baru yang tidak ada sangkut-pautnya dengan Masyumi. ${ }^{61}$

Tanggal 20 Pebruari 1968 kehadiran Partai Muslimin Indonesia (Parmusi), sebagai partai politik disahkan dengan Surat Keputusan Presiden Nomor 70 Tahun 1968 dan menunjuk Jarnawi Hadikusumo (Muhammadiyah) sebagai ketua dengan sekretaris Jendral Lukman Harun dari organisasi yang sama. Kepemimpinan mereka dianggap sementara, dan akan disempurnakan melaluai sebuah konggres yang berlangsung di Malang yang direncanakan bulan Nopember 1968. Adapun calon terkuat adalah Mohammad Roem, bekas tokoh Masyumi. Hal ini telah diketahui oleh Ketua Harian Parmusi ketika menghadap Presiden Soeharto tanggal 28 Oktober 1968 untuk membicarakan konggres. Mereka tersentak dengan pernyataan Soeharto yang tidak mengizinkan masuknya tokoh-tokoh Masyumi ke dalam Parmusi, kemudian ditindak lanjuti dengan perintahnya melalui Sekretaris Negara Alamsyah mengirimkan telegram ketika Muktamar hampir usai bahwa pengangkatan Roem tidak disetujui. ${ }^{62}$

Usaha kedua umat Islam pada permulaan Orde Baru adalah tampak pada usaha Wakil Presiden pertama Indonesia Mohammad Hatta pada tahun 1966/67 untuk mendirikan Gerakan Demokrasi Islam Indonesia, bersama dengan generasi muda Islam yang pada umumnya belum aktif berpolitik pada masa Demokrasi Parlementer dan Demokrasi Terpimpin. Dimaksudkan setelah tiga bulan gerakan ini menjadi partai. Usaha ini juga tidak dibenarkan oleh Presiden. Awalnya BKAM ingin bersama-sama Hatta dalam mendirikan partai, namun karena terjadi persepsi berbeda, yaitu Hatta sebagaimana tahun

61 Ibid.

62 Ichlasul Amal, Regional and Central Government in Indonesian Politics West Sumatra and South Sulawesi 1949-1979, (Yogyakarta: Gadjah Mada University Press, 1992), hal. 126-127. Nasir Tamara, "Sejarah Politik Islam Orde Baru”, dalam Prisma, Nomor 5, Tahun XVII, 1988, hal. 43. Afan Gaffar, "Islam dan Politik dalam Era Orde Baru Mencari Bentuk Artikulasi yang Tepat” dalam Asep Gunawan (Ed.), Artikulasi Islam Kultural dari Tahapan Moral ke Periode Sejarah, (Jakarta: PT RajaGrafindo Persada, 2004), hal. 269. 
1930 ingin membangun partai kader, sedangkan BKAM yang mendapat dukungan banyak dari organisasi masyarakat. ${ }^{63}$

Setelah Jenderal Soeharto diangkat menjadi Presiden pada sidang kelima MPRS bulan Maret 1968, lantas membentuk Kabinet Pembangunan I, tokohtokoh NU yang masih duduk dalam kabinet ini adalah, Idham Chalid menjadi Menteri Kesejahteraan Rakyat, dan KH Muhamad Dahlan menjadi Menteri Agama. Barulah pada Kabinet Pembangunan II pada tahun 1978 dibentuk untuk pertama kalinya NU tidak mempunyai wakil yang duduk di kabinet sejak partai itu didirikan. ${ }^{64}$

Nahdlatul Ulama (NU) partai Islam satu dari 9 partai yang boleh hidup terus oleh Orde Baru, yang lainnya adalah PNI, PSII, Parkindo, Partai Katolik, PERTI, IPKI, Murba dan Partindo partai-partai inilah ditambah dengan Parmusi dan Golkar menjadi kontestan Pemilihan Umum (Pemilu) 1971. Dalam Pemilu 1971 suara NU di atas suara yang pernah diperolehnya di Pemilu tahun 1955. Di zaman Demokrasi Terpimpin, NU juga ikut menikmati kekuasaan pemerintah, Ketua NU pada waktu itu, Idham Chalid, menjabat Wakil Perdana Menteri, dan masih banyak lagi kementerian yang dipegang oleh tokoh-tokoh NU yang lain. Demikian juga pada Kabinet Dwikora yang dibentuk setelah G-30-S/PKI tokoh-tokoh NU masih mendapat jabatan penting. Mereka itu Idham Chalid sebagai Menko Kesejahteraan Rakyat, Saifuddin Zuhri sebagai Menteri Agama, Aminuddin Aziz sebagai Menteri Negara, KH Fatah Yasin sebagai Menteri Penghubung Alim Ulama yang kemudian diganti oleh $\mathrm{KH}$ Mohamad Ilyas. Jumlah pejabat dalam kementerian ini mengalami pengurangan setelah Kabinet Ampera (1966), dan Subchan ZE duduk sebagai Wakil Ketua MPRS (1966-1971) serta KH. Sjaichu menjadi Ketua DPR-GR untuk masa jabatan yang sama. ${ }^{65}$

NU sebagai sebuah partai Islam yang besar pada tahun 1968 mengalami perpecahan di kalangan para pemimpinnya. Pada Muktamar di Bandung tanggal 3-9 Juli 1968, Subchan ZE yang menjadi Ketua I PB NU bertentangan keras dengan Idham Chalid Ketua Umum PB NU. Perpecahan ini sempat terekspos oleh beberapa surat kabar baik nasional maupun lokal. Perpecahan orang-orang nomor satu ditubuh NU tidak menjadikan surut semangat dalam

\footnotetext{
${ }^{63}$ Deliar Noer, "Islam dan Politik: Mayoritas atau Minoritas"...., hal..15.

64 Ibid.

65 Nasir Tamara, “Sejarah Politik Islam Orde Baru.....", hal. 44-45.
} 
membesarkan partai. Subhan pada Pemilu tahun 1971 menjadi bintang lapangan dalam berkampanye sehingga sering berhadapan dengan Menteri Dalam Negeri Amir Mahmud dalam berbagai persoalan. Dalam kampanyenya sering kali menggunakan kata "jihad" untuk membangunkan semangat politik umat Islam, karena itu mendapat kritik keras dari pemimpin NU sendiri. Kegigihan Subhan mendongkrak perolehan kursi NU dari hanya 47 kursi pada Pemilu 1955 menjadi 58 kursi pada Pemilu 1971. ${ }^{66}$

Setelah berhasil menuntaskan kebijakan terhadap kaum komunis dan nasionalis, maka target selanjutnya diarahkan pada kelompok Islam. Kebijakan terhadap kelompok Islam terbilang unik dibandingkan dengan kebijakan terhadap kelompok komunis dan nasionalis, karena sewaktu Orde Baru lahir, umat Islam yang telah memberikan kontribusi besar dalam kelahiran Orde Baru menyambutnya dengan antusias dengan harapan kelompok Islam dapat mengisi pemerintahan baru. Walaupun tergabung dalam Nasakom tapi kelompok Islam memiliki peran dan jasa besar dalam menghancurkan kekuatan komunis dan meruntuhkan rezim Soekarno selain karena kenyataan bahwa mayoritas penduduk Indonesia adalah penganut agama Islam.

Maka untuk menghormati dan menarik simpati tahap awal yang dilakukan oleh pemerintah Orde Baru untuk mencegah naiknya kekuatan politik Islam adalah membebaskan sejumlah mantan tokoh Masyumi. Tetapi sewaktu tokohtokoh mantan politisi Masyumi ini menuntut rehabilitasi terhadap Masyumi, rezim Orde Baru keberatan untuk memenuhinya karena partai ini dianggap telah menyimpang dari Pancasila dan UUD 1945. Penolakan pemerintah yang didukung oleh ABRI mengandung perasaan anti partai yang meluas di kalangan anggota koalisi Orde Baru, terutama di kalangan perwira Angkatan Darat dan intelektual pembaharu. Tidak kalah pentingnya adalah orang-orang yang berada di lingkungan Soeharto pada kurun lima tahun awal era Orde Baru banyak didominasi oleh tokoh-tokoh yang memiliki pandangan yang tidak simpatik terhadap kelompok Islam. ${ }^{67}$

Penolakan ini didasarkan atas ketakutan Orde Baru akan bangkitnya kekuatan politik Islam, selain juga karena keterlibatan Masyumi atas pem-

\footnotetext{
66 Ibid., hal. 45-46.

67 Aminuddin, Kekuatan Islam dan Pergulatan Kekuasaan di Indonesia Sebelum dan Sesudah Runtuhnya Soeharto, (Yogyakarta: Pustaka Pelajar, 1999), hal. 86.
} 
berontakan daerah yang membuat kelompok militer, terutama para jenderal abangan yang umumnya mempunyai hubungan kuat pada tradisi budaya Jawa, terutama mereka yang berasal dari Komando Daerah Militer Diponegoro (Jawa Tengah) dan Brawijaya (Jawa Timur) dipandang sangat teguh berpegang pada tradisi Jawa, dan di awal Orde Baru adalah perwira-perwira militer inilah yang menjadi kepercayaan dan orang dekat Soeharto) ${ }^{68}$ yang dimotori oleh Letnan Jenderal Ali Moertopo di lingkaran Soeharto yang anti Islam menolak rehabilitasi Masyumi.

Untuk mengurangi kekecewaan umat, Orde Baru lewat Jenderal Ali Moertopo, seorang perwira tinggi intelijen yang dikenal luas dengan manuvermanuver politiknya mendirikan Partai Muslimin Indonesia (Parmusi) tahun 1968. Pada awalnya yang akan menjadi pemimpin Parmusi adalah Mintareja, seorang intelektual Islam. Tetapi kemudian lewat manuver politik Ali Moertopo, Mintareja mendadak digantikan oleh John Naro. Demikian pula dengan NU sebagaimana telah dijelaskan di atas, mengharapkan konsesi-konsesi politik dalam kekuasaan juga mengalami kekecewaan karena dari personalia kabinet pertama Orde Baru, hanya satu posisi (Menteri Agama, Idham Chalid) yang diberikan kepada NU, sisanya personalia kabinet diisi kalangan sekuler dan Islam abangan. Sikap Orde Baru memperlakukan umat Islam bagaikan anak tiri ini semakin melambungkan kekecewaan umat Islam.

Pada awal era Orde Baru, partai-partai Islam menuntut pemerintah untuk menghidupkan kembali Piagam Jakarta pada Pembukaan UUD 1945, tetapi usaha ini sia-sia karena TNI tidak menjadikan agenda pada pembahasan di MPR 1966-67. Perlu dicatat meskipun Piagam Jakarta tidak diterima untuk dimasukkan dalam UUD 1945 oleh Soeharto, tetapi syariah dapat dikemas dalam

68 Ibid.,hal. 87. Priyayi, santri dan abangan adalah tiga istilah antropologis yang sudah akrab di kalangan umatIslam Jawa. Secara kultural, priyayi awalnya digunakan untuk menyebut pegawai atau pejabat pemerintah kerajaan pada masa pemerintahan Belanda dan kelompok pegawai pemerintahan setelah kemerdekaan. Santri digunakan untuk menyebut kelompok muslim yang taat dalam menjalankan agama. Sementara abangan sebaliknya, yakni sebutan untuk muslim yang tidak taat dalam menjalankan agama, terutama dalam wilayah ubudiyah. Dalam sosiologi Jawa masing-masing kelompok itu merupakan paguyuban yang seolah-olah saling membuat batas wilayah pergaulan sosiologisnya secara eksklusif. Masing-masing mempunyai budaya dan pola hubungan sosial sendiri-sendiri, sehingga nampak eksklusif. Paparan terkenal untuk pembagian dikotomi ini, lihat Clifford Geertz, The Religion of Java, (London: The Free Press,1964), hal. 6. 
UU sebagai hukum nasional. Perdebatan ini ditutup dengan Inpres Nomor 13 Tahun 1968 yang menyebabkan gerakan politik Islam bisa ditekan atau dimarginalkan. Maka sejak itulah hubungan umat Islam dengan pemerintah menjadi tegang, jika tidak boleh dikatakan bermusuhan, dan bersifat terbuka. Sejak itulah partai-partai politik Islam dan aktivis Islam diperlakukan sebagai warga negara yang terkekang dan politisi yang marginal.

\section{b. Ketegangan Politik Umat Islam dan Pemerintah (1969-1989)}

Hubungan antagonistik adalah hubungan yang mencirikan adanya ketegangan antara negara dengan Islam. Ini terjadi pada masa kemerdekaan sampai pascarevolusi. Pada era ini Islam dianggap sebagai pesaing kekuasaan yang dapat mengusik basis kebangsaan negara. Hal tersebut mengakibatkan negara menghalangi dan melakukan pengekangan terhadap gerak ideologi politik Islam.

Ketegangan ini ditambah dengan terbitnya UU No. 15 Tahun 1969 tentang Pemilihan Umum dan UU Nomor 16 Tahun 1969 tentang Susduk MPR/ DPR/DPRD dengan alasan demi stabilitas yang dapat memperlancar pembangunan ekonomi, pemerintah telah membangun format baru politik Indonesia yang memungkinkan pemerintah sangat kuat secara politis dan untuk itu lembaga legislatif diisi oleh eksekutif melalui kewenangan Presiden. Ditambah lagi dengan munculnya Pancasila sebagai 'Asas Tunggal' pada tahun 1983 bagi parpol dan ormas sehingga menjadi sulit untuk memperjuangkan berlakunya secara formal dan eksklusif hukum-hukum Islam. ${ }^{69}$ Rupanya Inpres tersebut di atas juga menjadi senjata pamungkas untuk mengakhiri perdebatan dasar negara bahwa UUD 1945 tidak dijiwai oleh Piagam Jakarta. Dan ini sangat berbeda dengan Dekrit Presiden 5 Juli 1959 yang mengatakan bahwa UUD 1945 dijiwai Piagam Jakarta.

Pola konfrontatif ini, mulai terbentuk sejak keluar Inpres no. 13 Tahun 1968, dan diimplentasikan pada tahun 1971, yaitu pada pemilu 1971 tatkala Golkar menang secara mayoritas dalam Pemilihan Umum. Maka sistem kepartaian menjadi hegemony party system. Untuk mempertahankan kemenangannya, perlu ada usaha sistematis memperkecil peran politik dari kekuatan partai politik yang lain dan, fusi partai pun menjadi sasarannya. Dikembangkan suatu

${ }^{69}$ Moh. Mahfud MD, “Perjuangan dan Politik Hukum Islam di Indonesia”... , hal. 70 
persepsi di kalangan birokrasi pemerintah bahwa Islam merupakan ancaman bagi kelangsungan jalannya pemerintah. Tekanan dan intimidasi kepada umat Islam terus digalakkan, pelarangan memakai jilbab di sekolah, penghapusan libur pada bulan Ramadan, sensor terhadap naskah-naskah khutbah Idul Fitri dan Idul Adha terus dilakukan. ${ }^{70}$

Pengurusan izin kegiatan keislaman dipersulit, dan tidak jarang seorang da'i atau mubalig yang sedang berceramah diminta turun dari mimbar dengan paksa oleh aparat karena dianggap merongrong kewibawaan pemerintah. Selain itu rupanya ada trauma di kalangan pemerintah akan bangkitnya kembali kekuatan Islam, yaitu ada keinginan di antara tokoh Masyumi untuk merehabilitasi namanya yang bubar pada tahun 1960; munculnya isu yang bersifat ideologis yakni menghidupkan kembali Piagam Jakarta dan menerapkan Islam sebagai dasar negara; ada keinginan untuk mendirikan partai politik yang baru; dan adanya beberapa tokoh Muhammadiyah yang berkeinginan menghidupkan kembali Partai Islam Indonesia yang belum berdiri karena persoalan intern ${ }^{71}$. Langkah untuk memperkokoh kekuatan rezim ini adalah dengan tumpuan kekuatan pada birokrasi, ABRI, dan Golkar, serta memilih justifikasi melalui cara-cara konstitusional sehingga perjalananya memang didasarkan pada aturan yang secara formal ada atau dibuat. ${ }^{72}$ Dengan kata lain pada periode ini negara menempatkan diri pada posisi hegemonik sedangkan Islam pada posisi pinggiran, sehingga keduanya saling berlawanan dan cenderung terlibat dalam konflik. ${ }^{73}$

Maka dengan menggunakan alat legal konstitusional ini, pemerintahan Orde Baru pun berhasil menampilkan sebagai pemerintahan yang menggunakan dan mematuhi hukum. Padahal dalam kenyataannya, apa yang dijalankan bukan rule of law, tetapi sebenarnya hanyalah rule by law. Jika dalam rule of law peraturan hukum dibuat dalam rangka memberikan jaminan perlindungan terhadap pelaksanaan hak-hak dasar warga negara, maka pada rule by law, peraturan hukum dibuat untuk melayani kekuasaan semata. Konskuensinya sistem

70 Abdul Azis Thaba, Islam dan Negara dalam Politik Orde Baru...., hal. 26.

71 Ibid., hal. 242-243.

72 Moh. Mahfud MD, Pergulatan Politik dan Hukum di Indonesia, (Yogyakarta: Gama Media, 1999), hal. 17.

73 Kubtowijoyo, Paradigma Islam, Interpretasi Untuk Aksi, (Bandung : Mizan , 1991), hal.142. 
politik demokratis yang ditegakkan hanyalah façade (topeng) belaka, karena pada hakekatnya yang berdiri adalah despotisme. Despotisme mempunyai ciri khas yaitu konsentrasi kekuasaan atau sang pemimpin, serta memusuhi setiap upaya yang mengarah pada pemberdayaan dan otonomi/kemandirian individu maupun kelompok dan organisasi dalam masyarakat ${ }^{74}$

\section{c. Hubungan Akomodatif (1985-1997)}

Memasuki periode terakhir dekade 1980-an setelah umat Islam dianggap lulus ujian dengan diterimanya Pancasila sebagai asas, pemerintah baru melangkah secara perlahan-lahan mengambil kebijaksanaan yang akomodatif 75 terhadap Islam dengan pasti memberikan porsi perhatian kepada umat Islam yang lebih dari memadai, yaitu diawali pada periode Kabinet Pembangunan V (1988-1993) dan diteruskan pada Kabinet Pembangunan VI (1993-1998), kebijakan politik Mandataris MPR yang akomodatif terhadap Islam memang dapat dilihat dan dirasakan. Islam dan umat tidak "lagi" dipinggirkan dan disudutkan dari kekuasaan politik sehingga ajaran-ajarannya mulai dirasakan manfaatnya bagi kepentingan pembangunan dan kehidupan bangsa Indonesia. Keadaan sosio- politik pasca 1988 berpengaruh pula terhadap adanya iklim kondusif bagi berkembangnya gerakan positivisasi hukum Islam.

Hal ini ditandai dengan semakin besarnya peluang atau dilonggarkannya umat Islam dalam mengembangkan wacana politiknya serta munculnya kebijakan-kebijakan yang dianggap positif bagi sebagian besar umat Islam baik bersifat struktural, legislatif, infrastruktural dan kultural. ${ }^{76}$ Kebijakan ini terjadi karena pemerintah Orde Baru saat itu menyadari bahwa umat Islam merupakan kekuatan politik yang potensial, yang oleh karenanya negara lebih memi-

${ }^{74}$ Muhammad AS. Hikam "Politik Hukum di Indonesia dalam Konteks Reformasi dan Demokrasi"....., hal. 12.

75 Sebagian orang tidak sependapat dengan istilah politik akomodatif, lebih cenderung melihat pola hubungan tersebut dalam bentuk satu arah dan Islam digunakan pemerintah (presiden) untuk memobilisasian dukungan. Jadi Islam lebih banyak dimanfaatkan. Lihat Afan Gaffar, "Islam Dan Poltik Dalam Orde Baru Mencari Bentuk Artikulasi Yang Tepat” dalam Asep Gunawan (Ed.), Artikulasi Islam Kultural dari Tahap Moral ke Periode Sejarah, (Jakarta: PT. RajaGrafindo Persada, 2004), hal. 272.

76 Bahtiar Effendy, Teologi Baru Politik Islam., Pertautan Agama, Negara dan Demokrasi...., hal. 35 . 
lih akomodatif. Jika negara menempatkan Islam sebagai outsider maka konflik akan sulit dihindari yang akhirnya akan membawa imbas terhadap proses pemeliharaan NKRI.

Perkembangan akomodatif Islam ini dipengaruhi oleh banyak hal, di antaranya Islam perlu diakomodasi karena bila diabaikan akan menimbulkan masalah politik. Di kalangan pemerintah sendiri terdapat sejumlah figur yang tidak terlalu fobia terhadap Islam dan tentu saja secara internal ada perubahan persepsi, sikap dan orientasi politik di kalangan umat Islam itu sendiri. Sedangkan menurut Bahtiar Effendi bahwa bergesernya sikap politik Soeharto yang lebih cenderung ke Islam, karena pertama selama dua puluh lima tahun terakhir, umat Islam mengalami proses mobilisasi sosial-ekonomi dan meluasnya akses ke pendidikan tinggi modern. Mereka tertransformasikan ke dalam entitas level menengah, baik secara sosial, ekonomi maupun politik. Kedua, adanya transformasi pemikiran dan tingkah poltik generasi baru Islam. Umat Islam telah mengalami transformasi intelektual dan aktivisme yang semula bersifat legalistik-formalistik menjadi lebih substansialistik. ${ }^{77}$

Pertanyaan yang muncul kemudian adalah mengapa saling akomodasi politik, setelah sekian lama terjadi ketegangan hubungan antara Negara dan Islam? Untuk menjawab ini, Affan Gaffar menjelaskan beberapa alasan mengapa Negara melakukan akomodasi terhadap Islam. Pertama, pemerintah sudah menganggap bahwa Islam di Indonesia bukan lagi sebagai kekuatan yang dapat mengancam stabilitas politik nasional. Kedua, pemerintah melakukan akomodasi politik terhadap Islam dalam rangka usaha untuk mencari dukungan dari umat Islam. Ketiga, dengan akomodasi politik akan mudah mengatur politik Islam di Indonesia. Sementara itu dari kacamata kalangan Islam, politik akomodasi perlu di tempuh agar pertama umat Islam memiliki akses yang cukup dalam proses pengambilan kebijaksanaan nasional, dan sudah waktunya untuk bermain dengan memiliki akses yang kuat dalam pengambilan keputusan, tidak lagi sebagai pemain pinggiran. Kedua, akomodasi dilakukan sebagai imbalan atas kebijaksanaan pemerintah yang sudah mulai memperhatikan Islam, atau paling tidak pemerintah tidak memusuhi Islam untuk masa-masa 
yang akan datang, dan bahkan akan memperoleh imbalan yang lebih besar dalam skala politik nasional. ${ }^{78}$

Menurut Abdul Azis Thaba, munculnya sikap akomodatif negara terhadap Islam lebih disebabkan oleh adanya kecenderungan bahwa umat Islam Indonesia dinilai semakin memahami kebijakan negara terutama dalam konteks pemberlakuan dan penerimaan Asas Tunggal Pancasila. ${ }^{79}$

Sikap akomodatif pemerintah terhadap umat Islam dapat dilihat dari sejumlah indikator sebagai berikut:

1. Sejak kementerian Pendidikan dan Kebudayaan dipercayakan kepada Fuad Hasan dilakukan penghapusan larangan mengenakan jilbab. Sebelum SU MPR 1988, sejak tahun 1978 di lingkungan sekolah oleh Menteri Pendidikan dan Kebudayaan Daoed Yoesoef yang juga Direktur CSIS melarang siswa muslimah mengenakan jilbab yang berdampak pada banyaknya korban yang dikeluarkan oleh pihak sekolah. Kebijakan ini mendapat reaksi yang sangat keras dari umat Islam yang akhirnya larangan mengenakan jilbab dihapus oleh pemerintah, demikian pula larangan liburan pada bulan puasa dicabut.

2. Disetujuinya inisiatif pemerintah yang mengajukan RUU Sistem Pendidikan Nasional kepada DPR dan menjadi UU Sistem pendidikan nasional yang salah satu ketentuan dalam UU tersebut tercantum adanya pendidikan agama menjadi mata pelajaran wajib yang harus diberikan kepada anak didik dari Taman Kanak-kanak hingga Perguruan Tinggi. Sejumlah organisasi massa Islam berhasil melakukan dan lobi yang serius sehingga ketika RUU tersebut ditetapkan menjadi UU Sistem Diknas pada tahun 1989 beberapa pasal menyangkut peranan pendidikan agama sudah dimasukkan. Bahkan pada hari terakhir PPP berhasil melakukan amandemen di dalam penjelasannya bahwa "antara pengajar dan anak didik." Ini tentu saja tidak disenangi oleh kalangan Kristen/Katolik.

3. Kasus Tabloid Mingguan MONITOR, sebuah tabloid mingguan yang dibuat oleh kelompok Katolik tersebut memuat tulisan yang dianggap

78 Afan Gaffar, "Islam dan Poltik dalam Orde Baru Mencari Bentuk Artikulasi yang Tepat" dalam Asep Gunawan (Ed), Artikulasi Islam Kultural dari Tahapan Moral ke Periode Sejarah...., hal. 276.

79 Abdul Azis Thaba, Islam dan Negara dalam Politik Orde Baru...., hal.15. 
menghina Islam di Indonesia sehingga dengan cepat membredel tabloid tersebut, dan bahkan pemimpin redaksinya kemudian diadili dan dijatuhi hukuman lima tahun penjara.

4. Pengesahan RUU Peradilan Agama yang memuat ketentuan bahwa bagi mereka yang beragama Islam berlaku hukum Islam dalam masalah perkawinan, warisan, waqaf, hibah dan sodakoh. Kalangan non-Islam berpendapat bahwa dengan pengajuan RUU tersebut berarti pemerintah hendak memberlakukan kembali Piagam Jakarta. Mereka berhasil membentuk pendapat umum melalui media massa yang sangat berpengaruh, yaitu Kompas dan Suara Pembaharuan, dan Fraksi Karya pada awalnya sudah mendukung kelompok non-Islam. Namun setelah Presiden Soeharto sendiri memberikan jaminan bahwa pemerintah tidak akan memberlakukan Piagam Jakarta baru pembahasan RUU tersebut berjalan dengan baik, dan menjadi RUU Peradilan Agama, dan pembahasan lebih jauh tentang masalah ini penulis paparkan pada bab VI.

5. Ketika Munawir Sadzali menutup Muktamar Muhammadiyah di Yogyakarta pada tahun 1989 di hadapan peserta Muktamar, beliau mengumumkan bahwa Presiden Soeharto, melalui Yayasan Amal Bakti Muslim Pancasila, akan mengirim 1000 dai ke daerah-daerah transmigran. Mereka diberi jaminan hidup sebanyak Rp 100.000,- setiap bulannya, dan dilengkapi dengan sepeda untuk alat transport mereka.

6. Berdirinya ICMI yang diketuai oleh B.J. Habibie yang juga selaku Menristek pada tahun 1990. Dengan hadirnya ICMI berdampak pada akomodatif pemerintah terhadap umat Islam. Fenomena menarik ketika organisasi ini dibentuk di Malang, Presiden Soeharto sendiri hadir bersama dengan sejumlah pejabat tinggi negara. Hal ini menandakan bahwa pemerintah memberikan dukungan yang kuat bagi kehadiran ICMI. Bagaimana struktur organisasinya, bagaimana ikatan dengan birokrasi, bagaimana ICMI berperan dalam membina hubungan antara Islam dengan pemerintah, jelas memperlihatkan ke arah akomodasi.

7. Yang tidak kalah menarik adalah adanya komitmen Presiden Soeharto untuk membantu umat Islam membuat dan memperbaiki sarana peribadatan melalui Yayasan Amal Bakti Muslim Pancasila. Melalui Yayasan ini ratusan masjid sudah dibangun, dan tersebar di hampir seluruh pelosok tanah air. 
8. Dalam rangka mengisi keanggotaan MPR, sejumlah intelektual yang dikenal mempunyai latar belakang keislaman yang kuat diangkat menjadi anggota MPR. Mereka mewakili "golongan", bahkan individu yang sebelumnya dikenal sebagai salah seorang pengeritik pemerintah yang keras sekali menjadi anggota MPR. ${ }^{80}$

9. Disahkannya UU Perbankan tentang keberadaan Bank Muamalat Indonesia dengan sistem ekonomi syariat dan diperbolehkannya berdirinya bankbank yang berdasarkan sistem ekonomi syariat, maka berdirilah bank-bank perkreditan syariat (BPR Syariah).

10. Penghapusan Judi SDSB seusai SU MPR 1988.

11. Dijadikannya IMTAK (iman dan takwa) sebagai asas pembangunan nasional dalam GBHN 1993 yang merupakan produk SU MPR 1993. Melemahnya kekuasaan nama-nama seperti Beny Moerdani (Katolik/Militer) dan tiga ekonom terkemuka yang dijuluki "mafia berkley" atau singkatan "RMS" (Radius, Mooy, Sumarlin) pada Kabinet Pembangunan VI tahun 1993 disingkirkan oleh kelompok Islam (seperti Habibie, Adi Sasono, Mar’i Muhammad) dan digantikan perannya oleh Saleh Afif dan Mar'ie Muhammad, serta banyak menteri baru dari ICMI, sehingga menguatnya isu Islamisasi atau "penghijauan." di pemerintahan termasuk meliternya "militer hijau" (militer yang pernah mengenyam pendidikan agama sebagai santri).$^{81}$

Sedangkan sikap akomodatif umat Islam terhadap pemerintah, dapat dilihat dari sejumlah indikator perilaku politik yang sudah sangat umum dikenal masyarakat secara luas, yaitu:

a. Sejumlah tokoh Islam dan ulama memperlihatkan dukungan untuk memilih kembali Presiden Soeharto untuk masa jabatan 1993-1998. Berbeda dengan organisasi massa lainnya yang mungkin menghendaki adanya pola rekrutmen poltik yang lain dari masa-masa sebelumnya.

80 Afan Gaffar, "Islam dan Poltik dalam Orde Baru Mencari Bentuk Artikulasi yang Tepat" dalam Asep Gunawan (Ed.), Artikulasi Islam Kultural dari Tahapan Moral ke Periode Sejarah...., hal. 272-276.

81 Douglas E. Ramage, Politics in Indonesia Democracy, Islam and the Ideology of Tolerance, hal. 119, 231. Pdt. Aguswati Hildebarn dt Rambe, M.A., Islam dan Negara: Sebuah Analisa tentang Peranan Umat Islam dalam Kehidupan Berpolitik di Indonesia, dalam http:/ / www. Oaseonline.org/artikel/atinegaraislam.htm. Diakses 17 Mei 2011. 
b. Pada bulan Juli 1992, Muhammadiyah datang menemui Presiden Soeharto dengan maksud memberikan dukungan untuk dapat terpilih kembali untuk masa jabatan 1993-1998. Apa yang dilakukan oleh Muhammadiyah kemudian diikuti oleh sejumlah organisasi massa lainnya.

c. Puncak dari dukungan yang dilakukan oleh orang Islam kepada Presiden Soeharto adalah dengan diadakannya doa politik untuk kesehatan presiden dan agar pemilihan kembali Presiden Soeharto berjalan lancar. ${ }^{82}$

Mendekatnya Soeharto ke Islam adalah realitas politik yang dihadapi pada masa ini. Menurut sejumlah pengamat, bergesernya sikap politik Soeharto yang lebih cenderung ke Islam memunculkan tiga kemungkinan. Pertama adanya kooptasi pemerintah terhadap umat Islam. Pemerintah sebagai subyek menjadikan umat Islam sebagai obyek dan dimanfaatkan untuk tujuan politiknya. Kedua, adanya akomodasi pemerintah terhadap umat Islam. Pemerintah menyadari akan kekeliruannya di masa lalu. Sebagai balasannya, pemerintah mengakomodasi kepentingan umat Islam dengan cara mendekati, merangkul umat Islam dan memberikan tempat yang layak di dalam inner circle kekuasaan. Ketiga, suatu bentuk integrasi umat ke pemerintah. Di sini posisi umat sebagai pihak yang pro-aktif terhadap pemerintah. Umat Islam sebagai subyek melakukan integrasi ke dalam lingkar kekuasaan. Hal ini dapat juga dibaca sebagai keberhasilan umat Islam membuat jaringan dakwah hingga menembus lapisan kekuasaan tertinggi, yakni Presiden. ${ }^{83}$

Terjadinya perubahan politik hubungan umat Islam dengan pemerintah tidak lepas dari kasus kehadiran ICMI dalam masyarakat. Dijelaskan oleh Afan Gaffar bahwa ICMI berhasil membangun Islam dalam rangka mencari modus untuk mempersatukan potensi intelektualitas umat Islam. Namun dalam ekspresinya tidak jarang ICMI seperti “burung merak" yang mengepakkan sayap dengan bulunya yang gagah dan berkesan menantang lingkungan di sekitarnya. ${ }^{84}$ Dalam ungkapan yang senada bahwa hadirnya ICMI pada tanggal

82 Afan Gaffar, "Islam dan Poltik Dalam Orde Baru Mencari Bentuk Artikulasi yang Tepat" dalam Asep Gunawan (Ed.), Artikulasi Islam Kultural Dari Tahapan Moral ke Periode Sejarah...., hal. 275.

83 "Romantika Politik Islam Masa Orde Baru", dalam http:// serbasejarah wordpress. com/ 2009/ 12/17/ romantika-politik-islam-masa-orde-baru/. Diakses tanggal 19 Mei 2011.

${ }^{84}$ Afan Gaffar, “Islam dan Poltik dalam Orde Baru Mencari Bentuk Artikulasi yang Te- 
7 Desember 1990 di Kampus Brawijaya Malang dianggap sebagai momentum sejarah penting bagi umat Islam, dan perkembangan ini tidak saja berarti mulai mencairnya hubungan Islam dan negara melainkan juga telah ditemukannya rumusan mengenai hubungan Islam dan negara yang integral dan sesuai dengan kultur Indonesia. ${ }^{85}$

Sikap pro dan kontra terhadap keberadaan ICMI di kancah perpolitikan Indonesia menunjukkan betapa organisasi ini mempunyai bobot politik yang tinggi. Dari kalangan Islam hanya Abdurrahman Wahid yang menyatakan secara terbuka untuk tidak bergabung dengan ICMI, karena ia ingin menangani hal yang lain, tapi sebenarnya ia mempunyai hubungan dengan kalangan nonIslam yang baik sekali. ICMI dinilainya sebagai langkah mundur yang menuju ke arah sektarian politik Indonesia, Pada tahun 1991, Abdurrahman Wahid melawan ICMI dengan membentuk Forum Demokrasi, organisasi yang terdiri dari 45 intelektual dari berbagai komunitas religius dan sosial. Organisasi ini diperhitungkan oleh pemerintah dan pemerintah menghentikan pertemuan halal bi halal yang diadakan oleh Forum Demokrasi pada tanggal 20 April 1992. Pada saat itu menjelang Pemilu legislatif 1992. ${ }^{86}$

Dari uraian di atas bahwa sejarah perpolitikan di Indonesia semenjak dari kemerdekaan sampai runtuhnya rezim Orde Baru telah mencatat kontribusi yang berarti dari kalangan Islam namun ada upaya yang sistimatis dari penguasa pemerintah baik itu Orde Lama maupun Orde Baru terutama pada paruh pertamanya untuk melumpuhkan kekuatan politik umat Islam baik itu secara kelompok dengan pelarangan atau pembekuan partai politik maupun perorangan dengan penangkapan atau pemenjaraan pemipin politik umat. Pola ini adalah pola yang pernah diterapkan oleh Kolonial Belanda atas saran dari C. Snouck Hurgronje pada abad ke-19. Snouck Hurgronje menegaskan bahwa pada hakekatnya Orang Islam di Indonesia itu penuh damai, namun diapun tidak buta terhadap kemampuan politik fanatisme Islam, oleh karena

pat" dalam Asep Gunawan (Ed), Artikulasi Islam Kultural Dari Tahapan Moral ke Periode Sejarah..., hal. 282.

85 Jamhari, "Islam di Indonesia" dalam Ensiklopedi Tematis Dunia Islam, (Jakarta: PT. Ichtiar Baru Van Hoeve, 2002), VI: 362. Lihat Bahtiar Effendy, Islam dan Negara: Transformasi Pemikiran dan praktis Politik islam di Indonesia....., hal. 203.

86 Douglas E. Ramage, Politics in Indonesia Democracy, Islam and the Ideology of Tolerance...., hal. 158, 164 . 
itu musuh kolonialisme bukanlah Islam sebagai agama, melainkan Islam sebagai doktrin politik. ${ }^{87}$.

Oleh karena itu menurut Snouck Hurgronje umat Islam didorong dan dibiarkan melakukan ibadah atau pemerintah bersikap netral dalam persoalan ibadah, tetapi bertindak tegas terhadap setiap kemungkinan perlawanan umat Islam. Politik Snouck Hurgronje ini didasarkan atas analisa pemisahan anatara agama dan politik, ${ }^{88}$ atau melihat Islam ke dalam dua bagian, Islam religius dan Islam politik.

Pada paruh kedua rezim Orde Baru perpolitikan Indonesia juga mencatat sejarah hubungan umat Islam dengan pemerintah menunjukkan adanya sikap akomodatif, yang demikian ditandai dengan bangkitnya kelompok intelektual muslim bahwa sejumlah genersasi muda muslim memperoleh kenikmatan untuk mengenyam pendidikan tinggi dalam dan luar negeri pada perguruan tinggi yang sangat menonjol yang tidak pernah diperoleh pada masa sebelumnya. Sejumlah nama yang dapat disebutkan di sini, misalnya M. Amien Rais, A. Syafii Maarif, Kuntowidjojo, Yahya Muhaimin, Ahmad Watik Pratiknja, Umar Anggoro Jeni, Jamaluddin Ancok, Sofian Effendi di Yogyakarta. Sementara itu di Jakarta masyarakat mengenal intelektual muslim seperti Abdurrahman Wahid, Nurcholis Madjid, Johan Effendi, Amin Azis, Dawam Rahardjo, Adi Sasono, Sri Bintang Pamungkas, Aswab Mahasin. Di Bogor A.M. Saefuddin dan masih banyak lagi sejumlah nama di kota-kota seperti Bandung (kelompok Salman dan Mizan), Surabaya (kelompok Al-Falah), Malang, Semarang dan kota-kota lain di luar Jawa. Kesempatan tersebut jarang didapatkan oleh generasi muda Islam pada masa sebelum Orde Baru. Pada masa kolonial peluang ini paling besar diperuntukan bagi anak keturunan bangsawan, priyayi dan mereka yang beragama Kristen/Katholik yang memperoleh dukungan kuat dari gereja. ${ }^{89}$

87 Harry J.Benda, Bulan Sabit dan Matahari Terbit Islam Indonesia pada Masa Pedudukan Jepang....., hal. 43.

${ }^{88}$ H. Aqib Suminto, Politik Islam Hindia Belanda Het Kantoor voor Inlandsche zaken, (Jakarta: LP3ES, 1985), hal. 199.

89 Afan Gaffar, "Islam dan Poltik dalam Orde Baru Mencari Bentuk Artikulasi yang Tepat" dalam Asep Gunawan (Ed), Artikulasi Islam Kultural dari Tahapan Moral ke Periode Sejarah..., hal. 277- 278. 
Tujuan kebijakan pemerintah kolonial melakukan hal demikian adalah untuk menjadikan Indonesia modern bukan menjadi Indonesia Islam dan bukan pula yang diperintah oleh Adat, tetapi haruslah menjadi Indonesia yang diperbarat (weaternized Indonesia). Peradaban Belanda haruslah menggantikan peradaban tradisional priyayi, dan di atas semuanya, peradaban santri. ${ }^{90}$ Ini seiring dengan kebijakan Belanda untuk membawa masyarakat Indonesia menuju asosiasi dengan masyarakat Belanda yang tidak terlepas dari tujuan memelihara ketertiban keamanan di bawah kekuasaan Belanda, yakni menciptakan cita-cita Pax Neerlandica. ${ }^{91}$

Sejarah perpolitikan Indonesia juga mencatat bahwa mereka ternyata mampu mengisi kepemimpinan yang baru, menggantikan mereka yang merupakan generasi sebelumya. Pendatang baru ini mempunyai persepsi yang berbeda dengan sebelumnya dalam melihat Islam dan politik dalam konteks kehidupan politik Indonesia. Kepemimpinan Islam yang baru ini, mempunyai karakteristik yang sudah jauh berbeda dengan kepemimpinan pasca kemerdekaan. Hal ini disebabkan pertama, mereka mempunyai latar belakang pendidikan yang tidak lagi didominasi oleh pendidikan tradisional Islam di Jawa (pesantren). Pendidikan mereka adalah campuran antara ilmu pengetahuan umum dengan ilmu pengetahuan keagamaan. Hal ini jauh berbeda dengan kepemimpinan Islam pada masa pasca kemerdekaan.

Kedua, mereka adalah berprofesi dalam dunia akademik sebagai tenaga pendidik di suatu perguruan tinggi atau peneliti di kementerian masing-masing dan di lembaga-lembaga swasta. Ketiga, kebanyakan mereka tidak menjadi politisi profesional dan tokoh dalam sebuah partai politik sehingga tidak memilih jalan ke parlemen sebagai suatu cara mengartikulasikan kepentingan umat Islam di Indonesia. Dari sinilah terjadinya pergeseran yang fundamen-

90 Harry J. Benda, Bulan Sabit dan Matahari Terbit Islam Indonesia pada Masa Pendudukan Jepang....., hal. 47.

91 Menurut Douwes Dekker sebagaimana dikutip oleh Aqib Suminto, yakni damai di bawah naungan Belanda. Pernah diimpikan terciptanya suatu negara besar Belanda Raya, yang meliputi negara Belanda di Eropa Utara dan Indonesia di Asia Tenggara. Dua daerah yang berjauhan secara geografis ini diharapkan akan bergabung secara intim sekali. Hubungan Belanda Indonesia bukan atas dasar penaklukan, tapi secara sukarela orang Indonesia akan berasosiasi dengan Belanda. Lihat H. Aqib Suminto, Politik Islam Hindia Belanda Het Kantoor voor Inlandsche zaken...., hal. 14-15. 
tal yang menyangkut persepsi tentang tujuan perpolitikan Islam dan modus dalam berpolitik, yakni apa yang diperjuangkan tidak lagi seperti generasi kepemimpinan pasca kemerdekaan yang menghendaki Islam sebagai dasar negara, akan tetapi bagaimana Islam memperoleh representasi yang wajar dan proporsional sesuai dengan besarnya potensi umat Islam, dan bukan lagi menempati pada posisi pinggiran sebagaimana pada masa awal Orde Baru sampai dengan pertengahan tahun $1980-\mathrm{an}^{92}$ dan setelah itu, setidaknya bergeser pada dimensi kultural jika tidak dapat dikatakan tidak sama sekali berdimensi non-politik..$^{93}$

\section{Penutup}

Pada era pra kemerdekaan dan menjelang kemerdekaan umat Islam menjadi kekuatan politik diperhitungkan artinya menjadi kelompok politik yang menentukan Indonesia ke depan, demikian pula di awal kemerdekaan hingga menjelang lahirnya Orde Lama yang ditandai dengan Dekrit Presiden tanggal 5 Juli 1959.

Berbeda dengan di atas pada era Orde Lama atau Demokrasi Terpimpin bahwa hubungan umat Islam dan negara pada saat itu bahwa umat Islam dalam mensikapinya secara garis besar terdiri atas dua kelompok pola garis politik atau dua macam ijtihad politik yang berbeda. Ijtihad pertama bahwa umat Islam lebih baik masuk ke dalam sistem itu demi kepentingan Islam, sedangkan ijtihad kedua bahwa demi kepentingan Islam maka umat Islam harus melawan sistem itu. Dalam perkembangannya rezim Demokrasi Terpimpin (1959-1966) yang kemudian disebut Orde Lama ternyata tak mampu bertahan dari goncangan yang disebabkan oleh maraknya konflik politik di tingkat elit (Presiden Soekarno, Angkatan Darat dan PKI) yang saling bersaing, Soekarno bertindak sebagai penyeimbang antara dua kekuatan lainnya. Ditambah dengan krisis ekonomi yang menimpa seluruh bangsa dan nyaris ambruk. Puncak konflik politik di tingkat elit tersebut adalah peristiwa G-30-S/

92 Afan Gaffar, "Islam dan Poltik dalam Orde Baru Mencari Bentuk Artikulasi yang Tepat" dalam Asep Gunawan (Ed.), Artikulasi Islam Kultural Dari Tahapan Moral ke Periode Sejarah..., hal. 277- 278.

93 Lihat Bahtiar Effendy, Islam dan Negara, Transformasi Pemikiran dan Pemikiran Politik Islam di Indonesia, (Jakarta: Paramadina, 1998), hal. 46-47. 
PKI yang menumbangkan rezim Demokrasi Terpimpin serta meretas bagi peralihan kekuasaan dan pemerintahan Orde lama ke Orde Baru ditandai dengan turunnya Soekarno dari kursi kepresidenan pasca kudeta G-30-S/PKI pada tahun 1965.

Umat Islam yang telah memberikan kontribusi besar dalam kelahiran Orde Baru menyambutnya dengan antusias dengan harapan kelompok Islam dapat mengisi pemerintahan baru. Harapan untuk menjadi pembilang dan penyebut pada masa ini tidak lama. Dalam periode awal (periode bulan madu), tiga tahun awal dari pemerintahan rezim ini menampakkan corak yang cukup demokratis, yang ditandai dengan kehidupan pers yang relatif bebas, produk-produk MPRS yang penuh dengan komitmen atas demokrasi, HAM dan hukum, dan sebagainya, optimisme di kalangan umat Islam akan kehidupan demokrasi karena romantisisme perjuangan menumbangkan Orde Lama penuh dengan retorika demokrasi. Tetapi setelah itu sekitar tahun 1968 hubungan politik antara pemerintah dan umat Islam telah terbuka dengan jelas adanya suatu ketegangan. Islam dianggap sebagai pesaing kekuasaan yang dapat mengusik basis kebangsaan negara. Hal tersebut mengakibatkan negara menghalangi dan melakukan pengekangan terhadap gerak ideologi politik Islam.

Ketegangan atau antagonistik ini ditambah dengan terbitnya UU No. 15 Tahun 1969 tentang Pemilihan Umum dan UU Nomor 16 Tahun 1969 tentang Susduk MPR/DPR/DPRD dengan alasan demi stabilitas yang dapat memperlancar pembangunan ekonomi, pemerintah telah membangun format baru politik Indonesia yang memungkinkan pemerintah sangat kuat secara politis dan untuk itu lembaga legislatif diisi oleh eksekutif melalui kewenangan Presiden. Ditambah lagi dengan munculnya Pancasila sebagai 'Asas Tunggal' pada tahun 1983 bagi parpol dan ormas sehingga menjadi sulit bagi umat Islam untuk berperan menjadi faktor penentu seperti masa sebelumnya. Rupanya Inpres tersebut di atas juga menjadi senjata pamungkas untuk mengakhiri perdebatan dasar negara bahwa UUD 1945 tidak dijiwai oleh Piagam Jakarta. Dan ini sangat berbeda dengan Dekrit Presiden 5 Juli 1959 yang mengatakan bahwa UUD 1945 dijiwai Piagam Jakarta.

Bergesernya sikap politik (Akomodatif) Soeharto yang lebih cenderung ke Islam karena tiga kemungkinan. Pertama adanya kooptasi pemerintah terhadap umat Islam. Pemerintah sebagai subyek menjadikan umat Islam sebagai 
obyek dan dimanfaatkan untuk tujuan politiknya. Kedua, adanya akomodasi pemerintah terhadap umat Islam. Pemerintah menyadari akan kekeliruannya di masa lalu. Sebagai balasannya, pemerintah mengakomodasi kepentingan umat Islam dengan cara mendekati, merangkul umat Islam dan memberikan tempat yang layak di dalam inner circle kekuasaan. Ketiga, suatu bentuk integrasi umat ke pemerintah. Di sini posisi umat sebagai pihak yang pro-aktif terhadap pemerintah. Umat Islam sebagai subyek melakukan integrasi ke dalam lingkar kekuasaan. Hal ini dapat juga dibaca sebagai keberhasilan umat Islam membuat jaringan dakwah hingga menembus lapisan kekuasaan tertinggi (Presiden).

\section{DAFTAR PUSTAKA}

A. Syafii Ma'arif, Islam dan Politik di Indonesia pada Masa Demokrasi Terpimpin (1959-1965), (Yogyakarta: IAIN Sunan Kalijaga Press, 1988)

Abdurrahman Wahid, Pesantren: Studi tentang Pandangan Hidup Kiai [Jakarta: LP3ES, 1982]

Afan Gaffar, "Islam dan Politik dalam Era Orde Baru Mencari Bentuk Artikulasi yang Tepat" dalam Asep Gunawan (Ed.), Artikulasi Islam Kultural dari Tahapan Moral ke Periode Sejarah, (Jakarta: PT Raja Grafindo Persada, 2004) , Politik Indonesia: Tradisi Menuju Demokrasi, (Yogyakarta: Pustaka Pelajar, 1999)

Akhmad Satori, “Wacana Negara Islam dalam Parlemen Konstituante: Hubungan Antagonistik Islam dan Negara di Indonesia",Sabtu, 07 Juni 2008, dalam http:/ / sitisalbiahnur.blogspot.com/. Diakses 17 Mei 2011.

Aminuddin, Kekuatan Islam dan Pergulatan Kekuasaan di Indonesia Sebelum dan Sesudah Runtuhnya Soeharto, (Yogyakarta: Pustaka Pelajar, 1999)

Arbi Sanit, Sistem Politik Indonesia Kestabilan Peta Kekuatan Politik Dan Pembangunan, (Jakarta: CV Rajawali, 1987)

Arskal Salim and Azyumardi Azra, 'Introduction The State and Shari'a in the Perspective of Indonesian Legal Politics' dalam Arskal Salim and Azyumardi Azra (ed.), Shari a and Politics in Modern Indonesia, (Singapore: Institute of Southeast Asian Studies, 2003) 
Bahtiar Effendy, Islam dan Negara: Transformasi Pemikiran dan praktis Politik islam di Indonesia, (Jakarta: Paramadina, 1998.)

Clifford Geertz, The Religion of Java, (London: The Free Press,1964)

Deliar Noer, Islam Pancasila dan Asas Tunggal, (Jakarta: Yayasan Perkhidmatan, 1983)

Deliar Noer, "Islam dan Politik: Mayoritas atau Minoritas", dalam Prisma, Nomor 5, Tahun XVII, 1988

Douglas E. Ramage, Politics in Indonesia Democracy, Islam and the Ideologi of Tolerance, (London and New York: Routledge, 1995)

H. Aqib Suminto, Politik Islam Hindia Belanda Het Kantoor voor Inlandsche zaken, (Jakarta: LP3ES, 1985)

Haedar Nashir, Gerakan Islam Syari at Reproduksi Salafiyah Ideologis di Indonesia, (Jakarta: Pusat Studi Agama dan Peradaban (PSAP) Muhammadiyyah, 2007)

Harry J. Benda, Bulan Sabit dan Matahari Terbit Islam Indonesia pada Masa Pedudukan Jepang, alih bahasa: Daniel Dhakidae, (Jakarta: Pustaka Jaya, 1980) Ichlasul Amal, Regional and Central Government in Indonesian Politics West Sumatra and South Sulawesi 1949-1979, (Yogyakarta: Gadjah Mada University Press, 1992)

Kuntowijoyo, Paradigma Islam, Interpretasi Untuk Aksi, (Bandung: Mizan , 1991) Lance Castle, Birokrasi dan Masyarakat Indonesia, (Surakarta: Hapsara, 1983) M. Syafi'i Anwar, Pemikiran dan Aksi Islam Indonesia: Sebuah Kajian Politik tentang Cendekiawan Muslim Orde Baru, (Jakarta: Paramadina, 1995)

Moh. Mahfud MD, "Perjuangan dan Politik Hukum Islam di Indonesia" dalam Syamsul Anwar, Antologi Pemikiran Hukum Islam di Indonesia antara Idealitas dan Realitas, (Yogyakarta: Fakultas Syari`ah UIN Sunan Kalijaga, 2008)

"Politik Hukum Baru Menuju Supremasi Hukum Sebuah Antaran Akademis" dalam Khamami Zada - Idy Muzayyad (ed.), Wacana Politik Hukum dan Demokrasi Indonesia.

"Politik Hukum Islam di Indonesia" dalam Seminar Jurusan Jinayah Siyasah FakultasSyariah UIN Sunan Kalijaga pada 25 November 2006, bertempat di Aula Balai Diklat Depsos, Jogjakarta.

Politik Hukum di Indonesia, (Jakarta: PT RajaGrafindo Persada, 
Mohtar Masoed, Ekonomi dan Struktur Politik Orde Baru 1966-1971 (Jakarta LP3ES, 1989)

MR. AB. Kusuma, Lahirnya Undang-Undang Dasar 1945, (Jakarta: Badan Penerbit Fakultas Hukum Universitas Indonesia, 2004)

Muhammad AS. Hikam, "Politik Hukum di Indonesia dalam Konteks Reformasi dan Demokrasi", dalam Khamami Zada - Idy Muzayyad (ed.), Wacana Politik Hukum dan Demokrasi Indonesia, (Yogyakarta: Senat Mahasiswa Fakultas Syari ah IAIN Sunan Kalijaga1999)

Nasir Tamara, "Sejarah Politik Islam Orde Baru”, dalam Prisma, Nomor 5, Tahun XVII, 1988

Ratno Lukito, Hukum Islam dan Realitas Sosial, (Yogyakarta: Fakultas Syari'ah UIN Sunan Kalijaga, 2008)

Zamakhsyari Dhofier, Tradisi Pesantren: Studi tentang Pandangan Hidup Kiai, (Jakarta: LP3ES, 1974) 